\title{
The Schlaining quartz-stibnite deposit, Eastern Alps, Austria: constraints from conventional and infrared microthermometry and isotope and crush-leach analyses of fluid inclusions
}

\author{
Marta Sośnicka $^{1,2} \cdot$ Stefan de Graaf $^{3} \cdot$ Giulio Morteani $^{4} \cdot$ David A. Banks $^{5} \cdot$ Samuel Niedermann ${ }^{1} \cdot$ Malte Stoltnow $^{1,6}$. \\ Volker Lüders ${ }^{1}$ (1)
}

Received: 19 January 2021 / Accepted: 4 September 2021 / Published online: 1 November 2021

(c) The Author(s) 2021, corrected publication 2022

\begin{abstract}
Stibnite was mined until the end of the twentieth century in the Schlaining ore district, Austria, near the easternmost border of the Eastern Alps where windows of Penninic ophiolites and metasediments are exposed below Austroalpine tectonic units. In Early Miocene, structurally controlled small vein and metasomatic stibnite-quartz deposits were formed in Penninic Mesozoic calcareous marbles and calcite schists. Fluid inclusion studies identified two fluids involved in the mineralization: (i) a low-salinity, low- $\mathrm{CO}_{2}$ metamorphic fluid that precipitated quartz at approximately $240{ }^{\circ} \mathrm{C}$ and (ii) a stibnite-forming ore fluid that had a meteoric origin. There is no evidence of boiling or that the fluids mixed during mineralization. The ore components $\mathrm{Sb}$ and $\mathrm{H}_{2} \mathrm{~S}$ were leached by fluid/rock interaction from buried rock units. Stibnite mineralization occurred by cooling the ore fluid to below $300^{\circ} \mathrm{C}$, at less than $2000 \mathrm{~m}$ depth. Quartz precipitated at slightly lower temperatures, approximately contemporaneous with stibnite. Fluid migration and ore deposition are probably related to high heat flow during the exhumation of the Rechnitz Window in response to Neogene extension and/or shallow Early Miocene andesitic magmatism. The study emphasizes that data obtained from the analyses of gangue minerals alone cannot routinely be used to infer the origin and depositional conditions of the associated ore minerals.
\end{abstract}

\section{Introduction}

Hydrothermal stibnite (principal ore mineral of $\mathrm{Sb}$ ) deposits occur in different mineralization styles and settings. Low-sulfidation epithermal vein-type deposits, hot spring

Editorial handling: B. Lehmann.

Volker Lüders

volue@gfz-potsdam.de

1 GFZ German Research Centre for Geosciences, Telegrafenberg, 14473 Potsdam, Germany

2 Institute of Geosciences, Friedrich Schiller University Jena, Burgweg 11, 07749 Jena, Germany

3 Max Planck Institute for Chemistry, Hahn-Meitner-Weg 1, 55218 Mainz, Germany

4 Gmain 1, 84424 Isen, Germany

5 School of Earth and Environment, University of Leeds, Leeds LS29JT, UK

6 Institute of Earth and Environmental Science, University of Potsdam, Karl-Liebknecht-Straße 24/25, 14476 Potsdam, Germany deposits, some porphyry and molybdenum deposits, parts of orogenic gold or sediment-hosted Carlin-type gold deposits, sediment-hosted hydrothermal quartz-stibnite veins, some SEDEX-type deposits, or massive metasomatic carbonate replacement deposits are examples. In some deposits, stibnite mineralization is also associated with considerable concentrations of gold, mercury, silver, tin, tungsten, or base metals (e.g., Gumiel and Arribas 1987; Dill 1993, 1998; Peng et al. 2002; Wagner and Boyce 2003; Hagemann and Lüders 2003; Fan et al. 2004; Liu and Ye 2005; Yang et al. 2006; Buchholz et al. 2007; Bortnikov et al. 2010; Pohl, 2020).

Stibnite deposits have been mined worldwide from various geological settings, among which the carbonate replacement deposits (especially with high Au grades) have been the most economically important. Today, most of the world's Sb production comes from China (about 78\%), followed by Bolivia, Russia, South Africa, and Tajikistan. Sb is predominantly produced from epithermal gold-antimony deposits and/or carbonate replacement deposits. For example, the largest stibnite ore deposit in the world, the giant carbonate-replacement Xikuangshan deposit in China, has an average ore grade of 
about $4 \% \mathrm{Sb}$ and contains total $\mathrm{Sb}$ metal reserves of about 2,500,000 metric tons (e.g., Fu et al. 2020).

Stibnite was mined in the ore belts of the Rhenohercynian, Saxothurigian, and Moldanubian Zones in Western and Central Europe but also in SE Europe and in the Eastern Alps (Fig. 1). The last active stibnite mining in Europe ceased at the end of the twentieth century. The samples studied here originate from the Schlaining mining district, which is located at the very end of the Eastern Alps in the small Rechnitz ophiolite window (Burgenland, Austria). The former underground mining district comprises two areas, namely the Kurt and the Neustift ore districts (Fig. 2), where stibnite was mined in several pits until the closure of the last mine in 1990. The total production from strata-bound and vein-type stibnite mineralization over more than 200 years was about 1,000,000 tons of crude ore with an average $\mathrm{Sb}$ grade of about 5\% (Weber 1989), making Schlaining one of the most important antimony producers in Europe.

The origin and age of the unique Alpine stibnite deposit at Schlaining have provoked some debate and controversy. The proposed models have invoked synorogenic ore formation (e.g., Maucher and Höll 1968; Petrascheck 1978; Nawaratne 1989), epithermal ore formation due to hydrothermal activity triggered by Miocene andesitic volcanism in the Pannonian Basin (e.g., Hiessleitner 1947; Belocky et al. 1991; Pohl

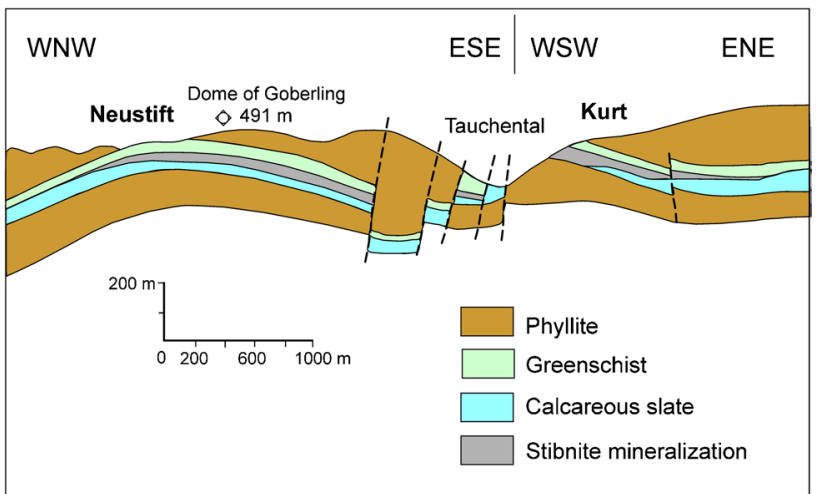

Fig. 2 Cross-section through the stibnite deposits of Neustift and Kurt in the Schlaining mining district after Pollak (1953)

and Belocky 1994), or ore deposition due to Neogene faultrelated fluid migration (Grum et al. 1992; Dunkl et al. 1998).

Here, we address the origin and formation of the former economic stibnite mineralization in the Schlaining mining district using conventional and near-infrared (IR) light microscopy, bulk analyses of cation and anion content, and $\delta^{2} \mathrm{H}, \delta^{18} \mathrm{O}$, and noble gas isotope ratios of fluid inclusions hosted in quartz and stibnite from strata-bound vein-type $\mathrm{Sb}$ ores.
Fig. 1 Geological map of the Eastern Alps and locations of former antimony mining districts (modified after Pohl and Belocky 1994). The studied stibnite mineralization of Schlaining occurs in the Rechnitz Window in the easternmost Alps

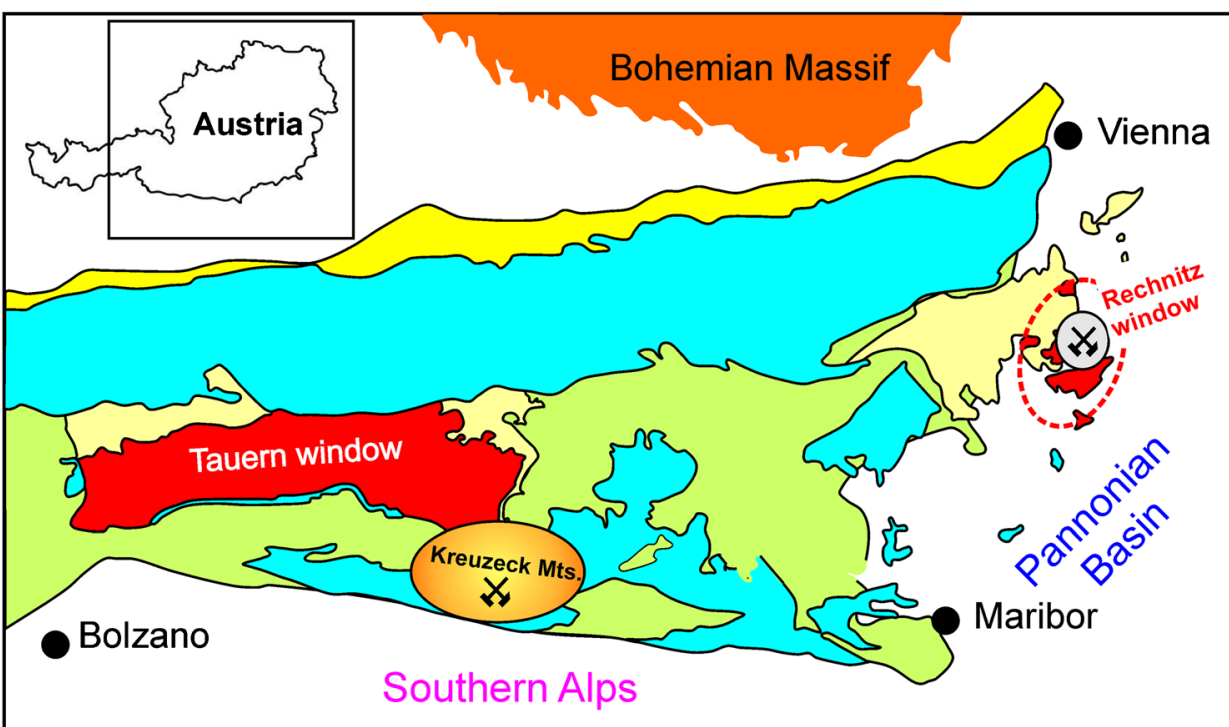

Austroalpine

Upper

Middle

Lower (undifferentiated)
Penninic windows (undifferentiated)

Flysch, Helveticum

Stibnite mineralization 


\section{Geological setting}

The Upper and Middle Austro-Alpine units of the Eastern Alps host a variety of mostly strata-bound sub-economic polymetallic ore deposits which belong to the so-called $\mathrm{Sb}-\mathrm{W}-\mathrm{Hg}$ formation according to Maucher and Höll (1968). The most important stibnite deposits were mined in the Rabant $\mathrm{Sb}-(\mathrm{As}, \mathrm{Au}, \mathrm{Cu}, \mathrm{Pb})$ district located in the southern part of the Kreuzeck mountain group (Fig. 1). The genesis of these Sb-accentuated deposits has been unclear for many years. For example, Höll (1978) related the $\mathrm{Sb}$ mineralization to the Upper Ordovician to Silurian hydrothermal activity triggered by submarine volcanism. In contrast, detailed studies of some Ag-(Au)-base metal deposits in the southern part of the Kreuzeck mountains have shown that these deposits were structurally controlled and probably related to fluid migration during the late Paleogene rather than Paleozoic hydrothermal events (Feitzinger et al. 1995). Thus, the early Paleozoic age for the strata-bound Sb-rich mineralization in the Eastern Alps as proposed by Höll (1978) is unlikely (W. Paar, pers. comm.).

The strata-bound, partly vein-type quartz-stibnite mineralization of the Schlaining mining district differs from the $\mathrm{Sb}-(\mathrm{As}, \mathrm{Au}, \mathrm{Cu}, \mathrm{Pb})$ mineralization of the Eastern Alps by the absence of W, Au, Ag, Hg, base metal ores, $\mathrm{S}$ isotope values, and age. The mineralization is hosted by Mesozoic metamorphic rocks of the Rechnitz Window at the very end of the Eastern Alps (Fig. 1). The rocks of the Rechnitz group belong to the Penninic calc-mica schists (Bündnerschiefer) series of the Upper Schieferhülle and consist of mafic, ultramafic, and metasedimentary rocks (Schmid 1956). The Rechnitz Window is bordered by rocks of the older Austroalpine unit and sediments of the Tertiary and Quaternary ages (Fig. 1).

Three metamorphic events are recorded in the rocks of the Rechnitz group: (I) ophiolite formation at temperatures exceeding $750{ }^{\circ} \mathrm{C}$ (Koller 1985) due to local oceanic hydrothermal activity with low spreading rates, (II) $65 \pm 6$ Ma-old subduction-related HP/LT metamorphism at temperatures of 330 to $370{ }^{\circ} \mathrm{C}$ and pressures of 6 to 8 kbar (Koller 1985), and (III) late Alpine greenschist metamorphism at temperatures between 350 and $430{ }^{\circ} \mathrm{C}$ and pressures up to $3 \mathrm{kbar}$ (Koller 1985; Hoinkes et al. 1999; Dunkl and Koller 2001). The rocks of the Rechnitz group were rapidly exhumed during the earliest Miocene. K/Ar dating of white mica from the western part of the Rechnitz Window yielded ages between 22 and $19 \mathrm{Ma}$ (data compilation in Dunkl 1992), which are similar to zircon fission track ages of 21.9 and 13.4 Ma (Dunkl 1992; Dunkl and Demény 1997). This age range overlaps that of the opening of the Pannonian Basin (21 to $15 \mathrm{Ma}$ ) related to the lateral escape of the Eastern Alps and Carpathian rollback subduction (Favaro et al. 2015). The age of the Schlaining stibnite mineralization is assumed to be between 19 and $17 \mathrm{Ma}$ and thus coeval with the Tertiary faulting of the area (Belocky et al. 1991; Grum et al. 1992; Dunkl et al. 1998).

According to Lehnert-Thiel (1967), Belocky et al. (1991) and Grum et al. (1992), the mineralization in the Schlaining mining district can be divided into three mineralization stages. Minor early-stage mineralization comprises pyrite, marcasite, arsenopyrite, sphalerite, and quartz. The subsequent main mineralization stage is nearly mono-mineralic, consisting of very pure stibnite with only trace amounts of other metals, with quartz and minor carbonate as gangue minerals (Lehnert-Thiel 1967; Grum et al. 1992). Trace ore minerals besides the massive stibnite are pyrite, sphalerite, and arsenopyrite. Minor late stage mineralization is polymetallic and contains cinnabar, fahlore, chalcopyrite, sphalerite, and stibnite (Lehnert-Thiel 1967; Belocky et al. 1991; Grum et al. 1992). Gangue minerals of this stage are calcite, ankerite, and quartz.

In the Neustift ore district (Fig. 2), massive stibnite mineralization occurs as a strata-bound ore layer hosted by $50-80-m$-thick dark gray chalk and/or mid-Cretaceous calcareous mica schists (Bauer 1966; Schönlaub 1973) directly below the contact to chlorite-rich greenschists. In the Kurt district (Fig. 2), strata-bound Sb mineralization was less abundant, and stibnite was mostly found in four WNW-ESE striking, steep parallel veins (Pollak 1953, 1955; Bauer 1966). The veins are irregularly formed, and there are metasomatic replacement and barren zones. Locally, fluid injected from the veins into bedding plane fissures hosted by calcite marble and greenschists and caused silicification of the rocks (Pollak 1953, 1955).

\section{Methods}

For this study, samples of massive stibnite $(16,066,16,070$, HUB in Table 1) and stibnite-quartz specimens $(16,064$, 16,065 , WL in Table 1) from the Schlaining antimony deposit were used.

\section{Fluid inclusion microthermometry}

Microthermometric measurements of fluid inclusions hosted in quartz from the stibnite mineralization were conducted using a Fluid Inc. USGS heating/freezing system mounted on a BX 50 Olympus microscope. Fluid inclusions in stibnite were studied using a Linkam heating/ freezing stage (THMS600 system) coupled to an Olympus BH2 UMA-IR infrared microscope with $a \times 50$ IR 


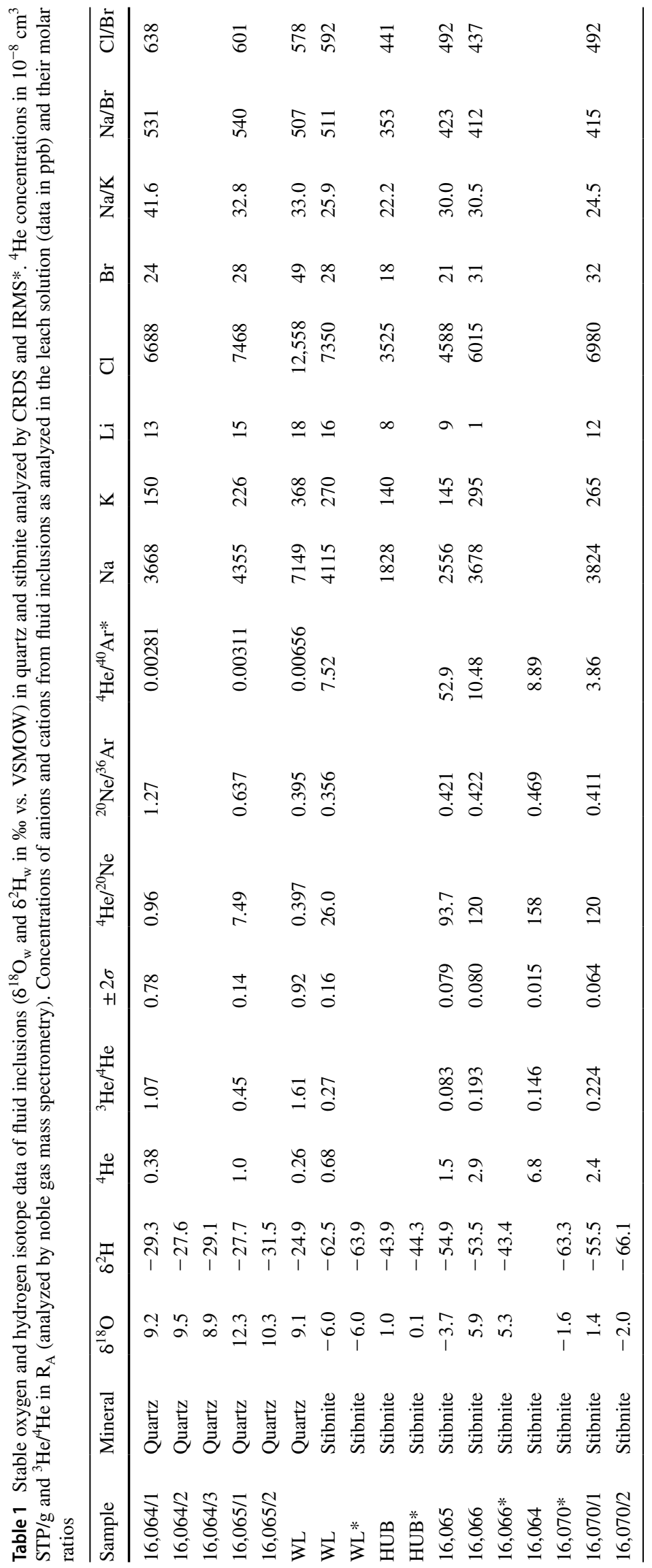


objective and a InGaAs IR camera that allows observation in the near-infrared region between $\lambda=800$ and $1800 \mathrm{~nm}$ (Lüders 2017). The InGaAs IR camera also allows observations of phase changes during microthermometric runs at the lowest light intensity of the used IR microscope (Lüders 2017). Thus, any analytical artifacts resulting from the heating of the samples by IR light (Moritz 2006; Peng et al. 2020) can be excluded. Both heating and freezing stages were calibrated with synthetic fluid inclusion standards supplied by Synflinc. Fluid properties were calculated using the HOKIEFLINCS_H2O-NACL Microsoft Excel spreadsheet (Steele-MacInnis et al. 2012).

\section{Laser Raman spectroscopy}

The vapor bubbles of aqueous two-phase fluid inclusions hosted in quartz were analyzed for gas content $\left(\mathrm{CO}_{2}, \mathrm{~N}_{2}\right.$, $\mathrm{H}_{2} \mathrm{~S}, \mathrm{CH}_{4}$ ) using a LabRAM HR Evolution (Horiba Jobin YvonTechnology) instrument at an excitation wavelength of $532 \mathrm{~nm}$ (green laser). For internal calibration, silicon $\left(520 \mathrm{~cm}^{-1}\right)$ was used. Raman spectra of gases in fluid inclusions were acquired in the spectral range between 1200 and $3000 \mathrm{~cm}^{-1}$. A $3 \times 30 \mathrm{~s}$ acquisition time was used for the measurements of aqueous inclusions.

\section{Bulk crush-leach analysis}

Bulk crush-leach analysis of fluid inclusions was carried out at the University of Leeds following the methodology described in detail by Banks et al. (2000). In total, 3 samples of quartz and 5 samples of stibnite were chosen for the analysis. All samples were carefully inspected for fluid inclusion abundances (primary, pseudo-secondary, secondary fluid inclusions) prior to analysis. One stibnite sample (WL) hosts abundant secondary fluid inclusions that are arranged along trails in large stibnite crystals. Primary fluid inclusions are less frequent in this sample.

Samples of quartz and stibnite were crushed to 1-2-mm grain size and cleaned by boiling several times in $18.2 \mathrm{M} \Omega$ water and dried prior to the analysis. Approximately 0.5 to $1 \mathrm{~g}$ of purified sample material was manually crushed with an agate mortar and pestle. The resulting mineral powder was leached with 18.2 $\mathrm{M} \Omega$ water and filtered through a 0.2$\mu \mathrm{m}$ Nylon filter prior to the analysis. Ion chromatography was used for the analysis of the anions $\mathrm{Cl}^{-}, \mathrm{Br}^{-}$, and $\mathrm{SO}_{4}{ }^{2-}$ in the leachate solutions. The cations $\mathrm{Na}^{+}, \mathrm{K}^{+}$, and $\mathrm{Li}^{+}$were measured using flame emission spectroscopy. The detection limits for the elements analyzed are as follows: $\mathrm{Na}=20 \mathrm{ppb}$, $\mathrm{K}=25 \mathrm{ppb}, \mathrm{Li}=1 \mathrm{ppb}, \mathrm{Cl}=20 \mathrm{ppb}$, and $\mathrm{Br}=1 \mathrm{ppb}$. With an average precision, as determined from a series of replicate analyses, of better than $10 \%$ relative standard deviation.

\section{Isotope analyses}

In total, 16 samples of quartz and stibnite were analyzed to determine the $\delta^{2} \mathrm{H}$ and $\delta^{18} \mathrm{O}$ values of the fluid inclusion water. Part of the samples used for the isotope analysis was the same as used for crush-leach analysis and fluid inclusion microthermometry. The samples were analyzed by two distinct techniques at the Max Planck Institute for Chemistry in Mainz. Both techniques allow for online sample analysis but work on fundamentally different continuous flow analyzers. One technique uses an isotope ratio mass spectrometer (IRMS) that is connected to a mechanical crushing unit. The analytical line uses a cold trap to collect fluid inclusion water that is released from crushing. When heating the cold trap, the sample water is liberated and passes through a pyrolysis furnace, where it is thermally separated into $\mathrm{H}_{2}$ and $\mathrm{CO}$ gas, which can separately be measured in the IRMS. The other technique couples an online mechanical crushing unit to a cavity ringdown spectroscope (CRDS). The analytical setup runs on a nitrogen carrier gas that is moisturized by a standard water to remove memory effects from which the instrument suffers when run with a dry carrier gas. Fluid inclusion water released by crushing a sample is measured on top of the standard water background. Isotope values can then be calculated by subtracting the standard water background from the sample peaks. The technical specifications, methodology, and calculation protocols of both analytical lines are explained in detail in de Graaf et al. (2020a).

The ${ }^{18} \mathrm{O} /{ }^{16} \mathrm{O}$ ratios of the quartz samples were measured using the Potsdam large geometry CAMECA 1280-HR SIMS according to the method proposed by Ramsey and Wiedenbeck (2018).

Noble gas analysis was performed using samples of 0.32 to $1.9 \mathrm{~g}$ of hand-picked quartz and stibnite mineral separates. The samples were loaded into an ultrahigh-vacuum spindle crusher, which was pumped at room temperature for at least $24 \mathrm{~h}$ to remove the atmospheric gases adsorbed on grain surfaces. For gas extraction, the samples were crushed under vacuum, and the gases released were admitted to the preparation line. Water was frozen in a dry ice-cooled trap, and other chemically active species were removed in Ti sponge and $\mathrm{ZrAl}$ getters. The noble gases were then separated from each other in a cryogenic adsorber, and noble gas concentrations and isotopic compositions were determined in a VG5400 noble gas mass spectrometer according to the procedures described by Niedermann et al. (1997).

\section{Results}

\section{Stibnite-quartz relationship}

Host rocks in contact with the stibnite mineralization are hydrothermally altered and intensively silicified (Fig. 3a), 


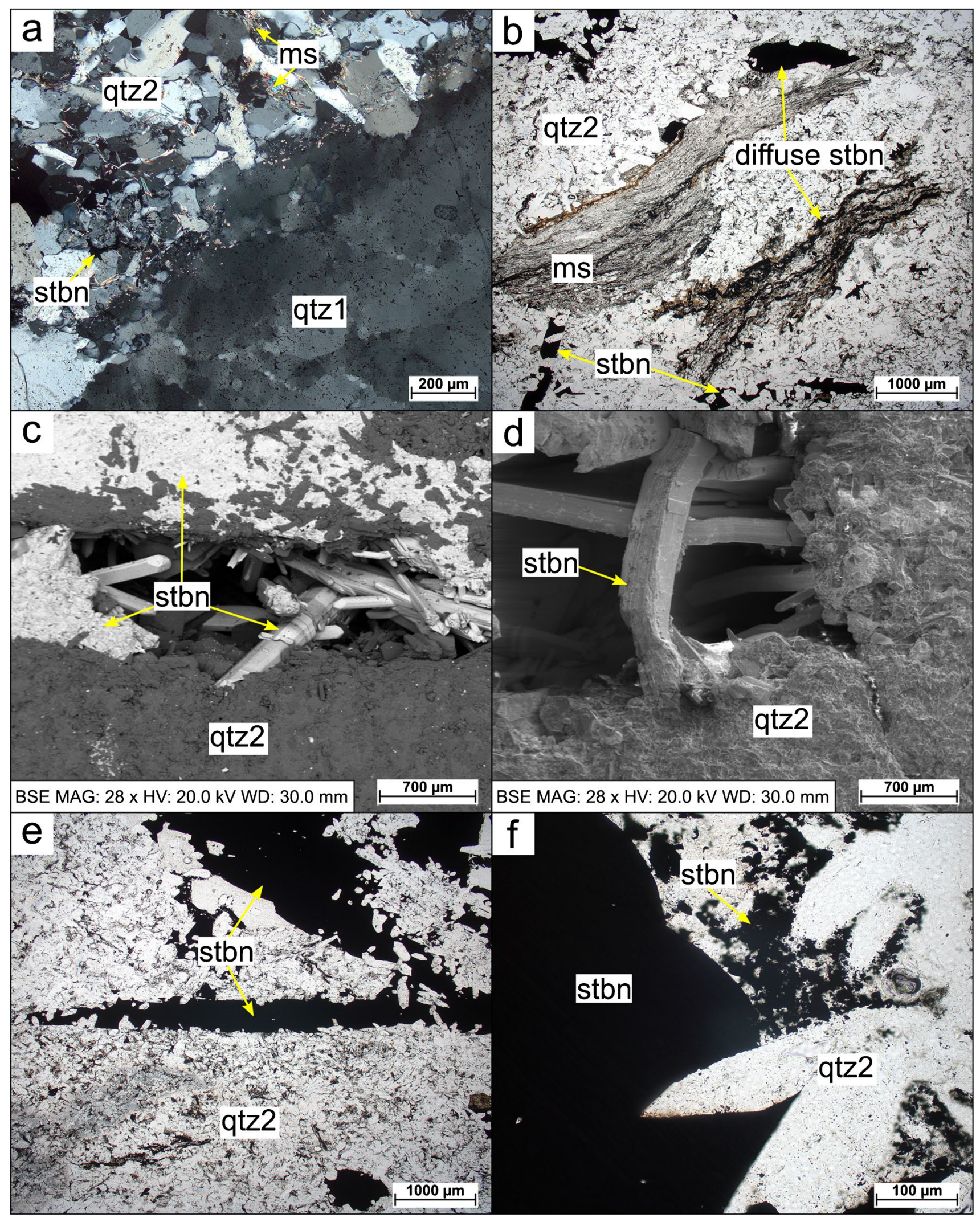


4Fig. 3 Photomicrographs and BSE images of stibnite and gangue quartz textures. a Replacement of country rock quartz (qtz1) locally showing stress-induced subdomains and needle-shaped mica (ms, marked by arrows). Stibnite (stbn) occurs interstitially between long prismatic hydrothermal quartz (qtz2) which shows a jigsaw texture. Transmitted light photomicrograph, crossed Nicols. b Dispersed stibnite mineralization in silicified country rock bordering a stibnite vein. Transmitted light photomicrograph, parallel Nicols. c BSE image showing stibnite crystals in vuggy country rock. d BSE image of euhedral stibnite crystals grown in open spaces of the veins showing ruptures and deformation. e Lath-shaped stibnite penetrated by long prismatic, euhedral quartz. Transmitted light photomicrograph, parallel Nicols. f Stibnite which is speared by euhedral quartz marginally etches the quartz crystal. Transmitted light photomicrograph, parallel Nicols

which was thought to indicate an epigenetic origin (e.g., Chovan et al. 2002). Locally, the host calcareous mica schists are impregnated by diffuse stibnite mineralization extending a few centimeters into the country rocks (Fig. 3b). Chemical analysis of calcareous schists near the contact with the stibnite veins that lack visible $\mathrm{Sb}$ mineralization has $\mathrm{Sb}$ and $\mathrm{As}$ concentrations between 24-47 and 11-78 ppm, respectively. The $\mathrm{Pb}$ concentrations are less than $3 \mathrm{ppm}$, and $\mathrm{Zn}$ concentrations are between 37 and $97 \mathrm{ppm}$ in the studied samples.

Euhedral stibnite crystals that precipitated in open spaces (Fig. 3c) in the veins are striated and, in some cases, fractured due to syn- and/or post-depositional deformation (Fig. 3d). Quartz commonly penetrates stibnite (LehnertThiel 1967; Belocky et al. 1991; Fig. 3e), and locally, the long prismatic quartz crystals are etched along their margins by stibnite which -together with stibnite infilling the interstices between grains (Fig. 3f) -suggests cogenetic precipitation of quartz and stibnite.

\section{Fluid inclusion petrography and microthermometry}

Stibnite samples from the Schlaining district have excellent transparency in near-infrared light as was observed for stibnite from other localities (e.g., Lüders 1996, 2017; Bailly et al. 2000; Shimizu 2018; Krolop et al. 2019). The stibnite crystals are typically striated in the direction of growth. Primary two-phase $(\mathrm{L}+\mathrm{V})$, aqueous fluid inclusions are elongated, occasionally as negative crystals oriented parallel to $\{110\}$ or $\{010\}$ (Fig. 4a-c). The orientation of pseudo-secondary fluid inclusions in stibnite is also crystallographically controlled, as trails are frequently oriented perpendicular to $\{110\}$ or $\{010\}$.

Secondary fluid inclusions are almost absent in the studied stibnite samples, except for sample WL which contains numerous, obvious secondary fluid inclusion trails that cut the margins of stibnite crystals (Fig. 4d). In general, secondary fluid inclusions are much smaller compared to primary inclusions (Fig. 4a-d).
Quartz associated with stibnite typically forms crusts of small crystals growing on the stibnite crystals or as infillings between crystals. There are abundant aqueous two-phase fluid inclusions and often fragments of stibnite incorporated during quartz crystallization. Primary aqueous two-phase fluid inclusions are located on growth zones (Fig. 4e) or are arranged in three-dimensional clusters and/or parallel crystal planes. The inclusions have elongated, negative crystal or rounded forms (Fig. 4f). Secondary aqueous two-phase fluid inclusions are also abundant in quartz occurring in trails along the healed fractures. Due to the high abundance of fluid inclusions in some quartz samples, it was often difficult or even impossible to determine clear age relationships between the fluid inclusion assemblages. Secondary modifications of fluid inclusions due to necking-down were also observed in some cases.

Visible $\mathrm{CO}_{2}$-bearing fluid inclusions were rarely observed in calcite samples from the main mineralization stage (Belocky et al. 1991) and are absent in stibnite and quartz. However, low $\mathrm{CO}_{2}$ concentrations and, in some cases, traces of $\mathrm{CH}_{4}$ were detected by Raman spectroscopy in the gas bubbles of two-phase fluid inclusions (Fig. 5). Melting of clathrate was not observed during freezing/heating, indicating that the quartz-forming fluid was not saturated with respect to $\mathrm{CO}_{2}$. Other gases such as $\mathrm{N}_{2}$ or $\mathrm{H}_{2} \mathrm{~S}$ were not detected by laser Raman spectroscopy.

During freezing runs, it was not possible to determine the first melting of ice in stibnite-hosted fluid inclusions. The final melting of ice in primary stibnite-hosted inclusions was measured between -4.5 and $-3.5^{\circ} \mathrm{C}$, corresponding to salinities of 5.7 to $7.2 \mathrm{wt} . \% \mathrm{NaCl}$ equiv. (Bodnar 1993) with the homogenization temperatures in a narrow range between 240 and $250{ }^{\circ} \mathrm{C}$ (Fig. 6). Pseudo-secondary fluid inclusions in stibnite have salinities similar to or only slightly lower than the primary fluid inclusions but have lower homogenization temperatures (Fig. 6). Secondary stibnite-hosted fluid inclusions have significantly lower salinities and homogenization temperatures which are similar to fluid inclusions in quartz (Fig. 6). The latter shows the first melting of ice between -11.1 and $-10.6{ }^{\circ} \mathrm{C}$, which is close to the eutectic temperature of the pure $\mathrm{H}_{2} \mathrm{O}-\mathrm{KCl}$ system. The final melting temperatures of fluid inclusions in quartz were measured between -2.0 and $-1.7^{\circ} \mathrm{C}$ indicating salinities between 2.9 and 3.4 wt.\% NaCl equiv. (Fig. 6). Homogenization temperatures of fluid inclusions in quartz are also lower than those of primary fluid inclusions in stibnite and are between 198 and $208{ }^{\circ} \mathrm{C}$ (Fig. 6).

\section{Crush-leach analyses}

The concentrations of anions and cations in stibnite- and quartz-hosted fluid inclusions released by crushing are plotted in $\mathrm{Na}-\mathrm{K}-\mathrm{Cl}-\mathrm{Br}$ diagrams (Fig. 7). Fluid inclusions in 


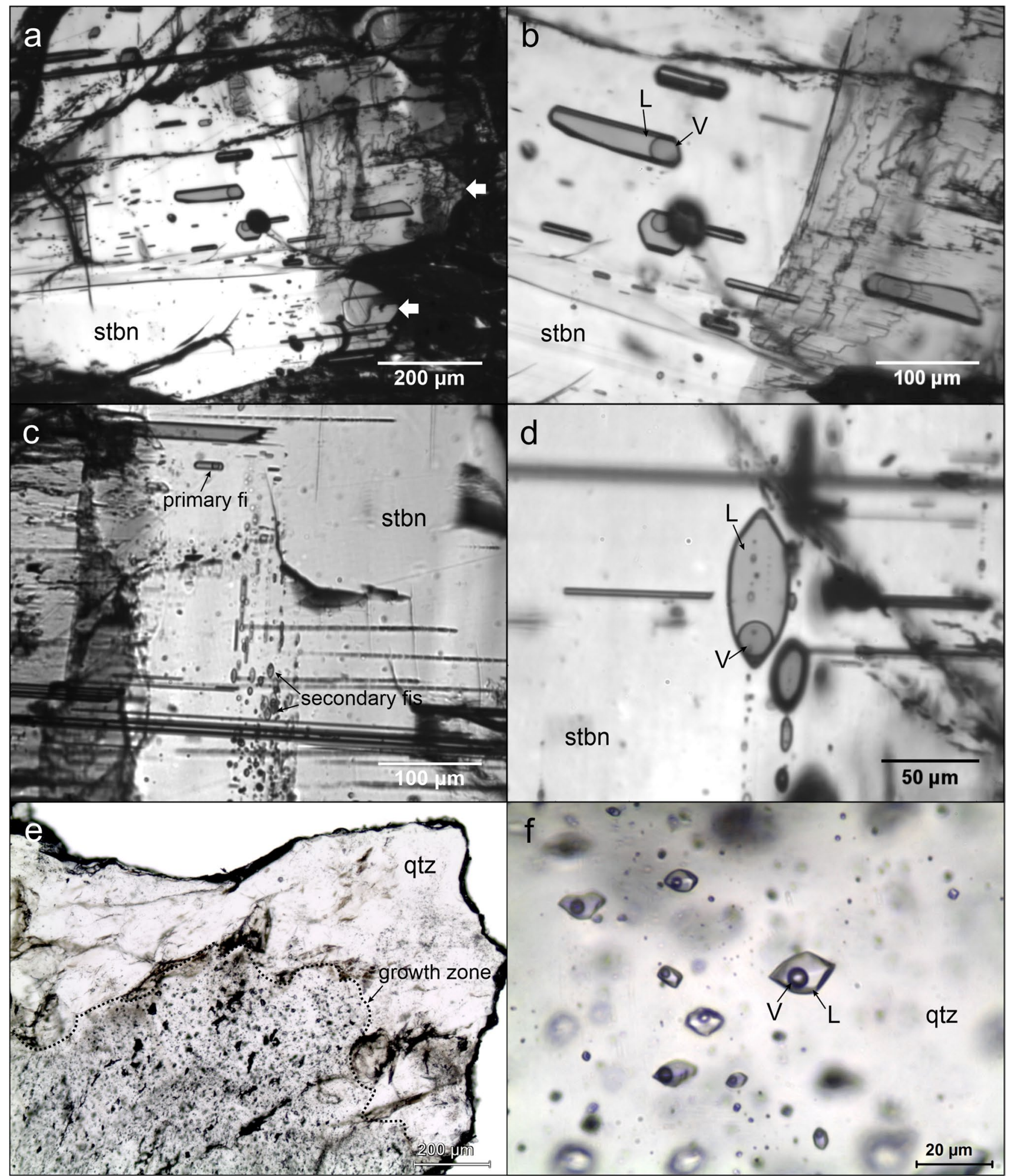

Fig. 4 Sequence of transmitted IR-light photomicrographs of stibnite (a-d) and transmitted-light photomicrographs (PPL) of quartz (e, f) from the Schlaining deposit. a Stibnite (stbn)-hosted primary aqueous two-phase $(\mathrm{L}+\mathrm{V})$ fluid inclusions oriented parallel to $\{110\}$, crystal terminations are indicated by white arrows. b Detailed field of view showing the section with primary fluid inclusions in a. c Primary fluid inclusions and secondary fluid inclusion trail showing contrasting orientations within the same field of view, sample WL. d Selected secondary two-phase $(\mathrm{L}+\mathrm{V})$ aqueous inclusion. e Growth zone (dotted line) with primary $\mathrm{CO}_{2}$-bearing aqueous two-phase $(\mathrm{L}+\mathrm{V})$ inclusions in quartz (qtz) crystal. f Assemblage of quartz-hosted negative crystal-shaped aqueous two-phase $(\mathrm{L}+\mathrm{V})$ fluid inclusions 


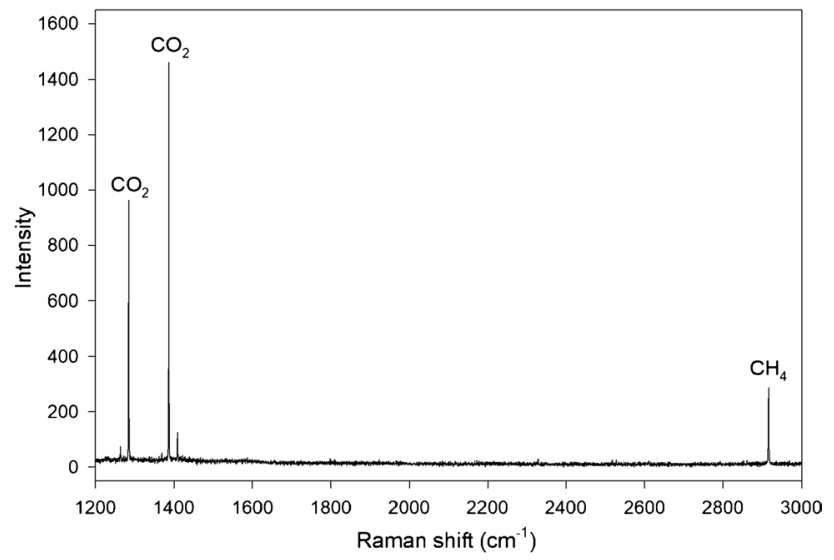

Fig. 5 Raman spectrum of the vapor bubble of an aqueous fluid inclusion in quartz showing $\mathrm{CO}_{2}$ and $\mathrm{CH}_{4}$ content

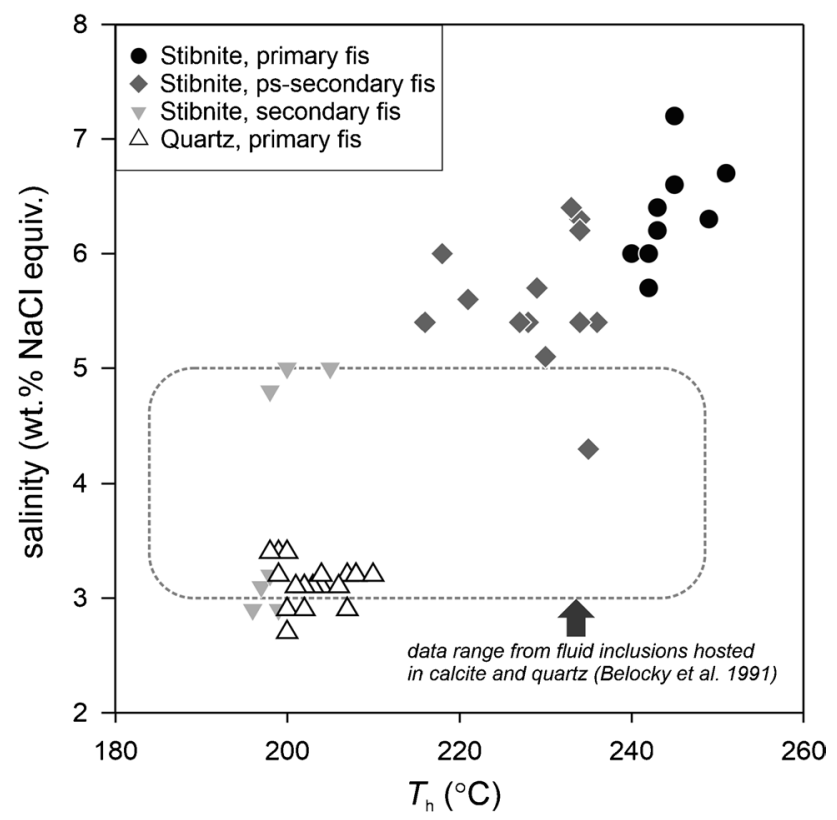

Fig. 6 Salinity vs. homogenization temperature $\left(T_{h}\right)$ of fluid inclusions (fis) hosted in stibnite and gangue quartz. Ranges of salinities and homogenization temperatures of quartz and calcite-hosted fluid inclusions (Belocky et al. 1991) are shown for comparison (dashed line)

quartz have $\mathrm{Cl} / \mathrm{Br}$ molar ratios similar or slightly lower than seawater whereas stibnite-hosted fluid inclusions (except the WL sample which contains abundant secondary fluid inclusions) have higher $\mathrm{Br}$ concentrations, thus having considerably lower $\mathrm{Cl} / \mathrm{Br}$ ratios. Fluids that do not lie on the seawater evaporation line have experienced water-rock interaction (WRI), where $\mathrm{Na}$ in the fluid has been exchanged for another cation, and therefore plot to the left of the evaporation line as indicated in Fig. 7a. For example, Na may be depleted in the fluid through exchange with Ca in plagioclase (Davisson
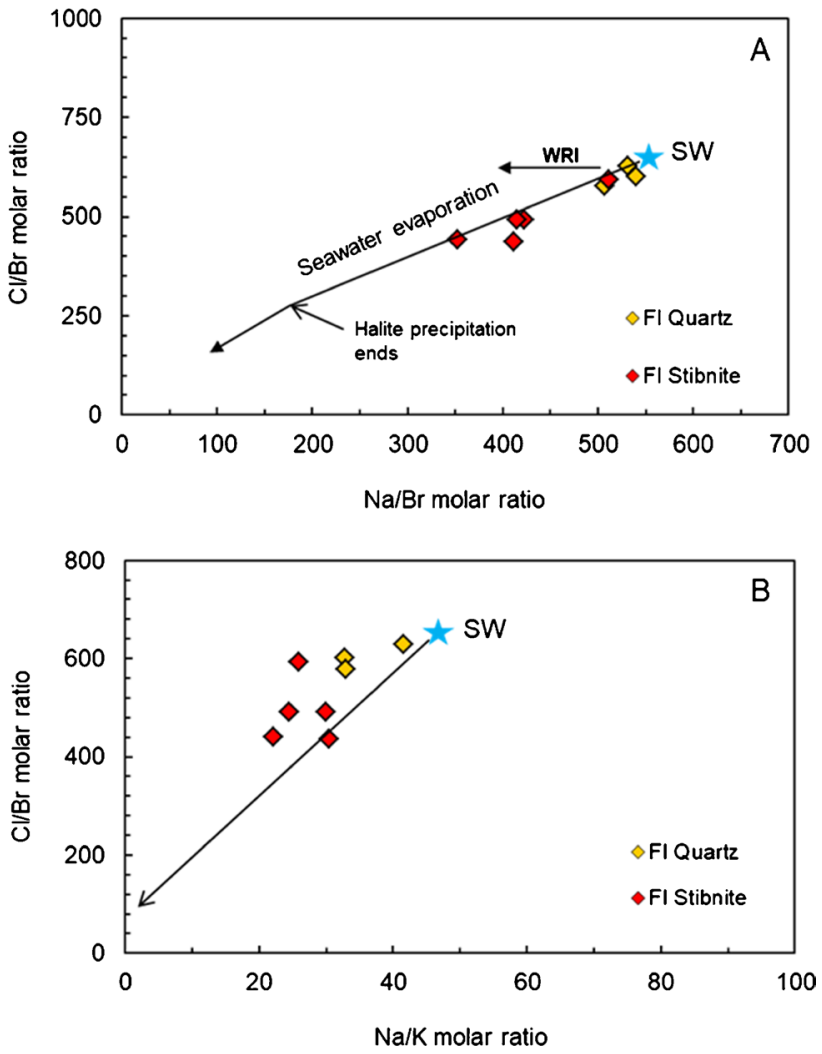

Fig. 7 a, b $\mathrm{Cl} / \mathrm{Br}$ vs. $\mathrm{Na} / \mathrm{Br}$ and $\mathrm{Na} / \mathrm{K}$ molar ratio diagrams. WRI, water-rock interaction; $\mathrm{SW}$, seawater

and Criss 1996) or through albitization of K-feldspar (Banks et al. 2002; Möller et al. 2017). Here, the majority of samples plot on or within error of the seawater evaporation line (Fig. 7a). However, since WRI does not affect the concentrations of chloride and bromide or their ratio in solution (e.g., Fontes and Matray 1993), the different $\mathrm{Cl} / \mathrm{Br}$ of fluid inclusions in quartz and stibnite suggest the fluids had different sources.

As observed for $\mathrm{Br}$, there is also a difference in the $\mathrm{K}$ contents of fluid inclusions hosted in stibnite and quartz. The $\mathrm{Na} / \mathrm{K}$ ratios of fluid inclusions in quartz are higher than those in stibnite-hosted fluid inclusions (Fig. 7b). However, in the $\mathrm{Na} / \mathrm{K}$ vs. $\mathrm{Cl} / \mathrm{Br}$ diagram (Fig. $7 b$ ), fluid inclusions in both quartz and stibnite show $\mathrm{K}$ enrichment relative to seawater, suggesting that $\mathrm{Na}-\mathrm{K}$ exchange reactions between fluids and minerals were an important process in the fluid evolution.

\section{Fluid inclusion isotope data}

Inclusion fluid isotope data were acquired from 10 stibnite samples and 6 quartz samples using IRMS and CRDS techniques with the analyses showing a good level of 
reproducibility between them. A complete overview of fluid inclusion water isotope analyses is presented in Table 1 and Fig. 8. Fluid inclusions in quartz have the highest isotope values, ranging from 5.6 to $12.3 \%$ for $\delta^{18} \mathrm{O}_{\text {water }}$ and -34.3 to $-24.9 \%$ for $\delta^{2} \mathrm{H}_{\text {water }}$ In contrast, stibnite has consistently lower values ranging from -6.0 to $5.9 \%$ for $\delta^{18} \mathrm{O}_{\text {water }}$ and always below $-40 \%$ for $\delta^{2} \mathrm{H}_{\text {water }}$. The lowest isotope values are recorded in the WL stibnite sample, which hosts abundant secondary fluid inclusions. Fluid inclusion water in stibnite and quartz from the Schlaining district plots in isotopically distinct fields in Fig. 8, suggesting different fluid sources for quartz and stibnite.

The $\delta^{18} \mathrm{O}$ ratio of the original quartz-forming fluid is uncertain, since in situ oxygen isotope re-equilibration between fluid inclusion water and quartz may cause a decrease in $\delta^{18} \mathrm{O}_{\text {water }}$ ratios after deposition (e.g., Rye and O'Neil 1968; Taylor 1997). SIMS analyses of oxygen isotope ratios in three quartz samples yielded $\delta^{18} \mathrm{O}_{\text {quartz }}$ values between 23.7 and $26.9 \%$. Using a mean $\delta^{18} \mathrm{O}_{\text {quartz }}$ value of $25.9 \%$ and a temperature of $270{ }^{\circ} \mathrm{C}$ (Belocky et al. 1991), a $\delta^{18} \mathrm{O}_{\text {water }}$ value of ca. $17.3 \%$ for the quartz-forming fluid can be calculated with the equation of Clayton et al. (1972). This calculated $\delta^{18} \mathrm{O}_{\text {water }}$ value is higher than the $\delta^{18} \mathrm{O}_{\text {water }}$ values measured in quartz samples and suggests that the latter may not represent the original values of the fluid (de Graaf et al. 2020b).

This study describes the first application of a CRDS system for fluid inclusion isotope analysis on vein-type deposits (de Graaf et al. 2020a). It has been argued that contaminant gases released during crushing, which may be especially abundant in vein minerals, could possibly interfere with measurements on CRDS instruments (Arienzo et al. 2013). In contrast, the cold trap procedure in the IRMS setups flushes through non-water gas before the analysis of the sample water. The good reproducibility between the IRMS and CRDS techniques thus indicates either that contaminant gases have a minor interference on the CRDS system or that there is a general scarcity of interfering gas in the samples. The successful analysis could be made on the CRDS system down to $0.03 \mu \mathrm{l}$, which is well below the commonly reported analytical size limitations of generally 0.1 to $0.2 \mu \mathrm{l}$ for fluid inclusion isotope analytical systems. This demonstrates the potential of CRDS systems for measuring small amounts of fluid inclusion water.

The isotopic and elemental abundances of noble gases in Schlaining quartz and stibnite fluid inclusions are presented in Table 1. Two quartz samples have ${ }^{3} \mathrm{He} /{ }^{4} \mathrm{He}$ ratios consistent with the atmosphere $\left(1 \mathrm{Ra}=1.39 \times 10^{-6}\right)$ within their rather large error limits, which are due to the low He concentrations. ${ }^{4} \mathrm{He} /{ }^{20} \mathrm{Ne}$ and ${ }^{20} \mathrm{Ne} /{ }^{36} \mathrm{Ar}$ ratios are also air-like for WL quartz, but distinctly higher ( 3 times atmospheric) for quartz sample 16,064. The third quartz sample 16,065 has a ${ }^{3} \mathrm{He} /{ }^{4} \mathrm{He}$ ratio of $(0.45 \pm 0.14) \mathrm{Ra}$ at ${ }^{4} \mathrm{He} /{ }^{20} \mathrm{Ne}$ more than 20 times atmospheric, indicating a mixture of predominantly crustal $\mathrm{He}(\sim 0.02 \mathrm{Ra}$; Ballentine and Burnard 2002) with a few percent of mantle He ( 6.1 $\mathrm{Ra}$; Gautheron and Moreira 2002).

The ${ }^{4} \mathrm{He} /{ }^{20} \mathrm{Ne}$ ratios of the stibnite samples are 80-500 times above the atmospheric value, at air-like ${ }^{20} \mathrm{Ne} /{ }^{\beta 6} \mathrm{Ar}$ (Table 1). Therefore, the atmospheric He contribution is negligible for all of them, and again, the ${ }^{3} \mathrm{He} /{ }^{4} \mathrm{He}$ ratios of $\sim 0.1-0.3 \mathrm{Ra}$ likely reflect a mixture of crustal He with 2-4\% mantle He. This is illustrated in Fig. 9, showing ${ }^{3} \mathrm{He} /{ }^{4} \mathrm{He}$ vs. ${ }^{4} \mathrm{He} /{ }^{20} \mathrm{Ne}$ ratios. All data, regardless of the mineral type, plot at about equal relative distances from the air-crust and air-mantle mixing lines, indicating that mantle $\mathrm{He}$ contributions are similar in all of them. The obvious difference is the contribution of atmospheric $\mathrm{He}$, which is considerably higher for the quartz samples than for the stibnite samples.

In addition to the atmospheric He contribution, the ${ }^{4} \mathrm{He} /{ }^{40} \mathrm{Ar} *$ ratio (where ${ }^{40} \mathrm{Ar} *$ is the non-atmospheric ${ }^{40} \mathrm{Ar}$ fraction) is also completely different for quartz and stibnite. In stibnite-hosted fluid inclusions, it is within the range of crustal or mantle production ratios ( 4-53; cf. Ballentine and Burnard 2002), whereas in quartz-hosted fluid inclusions, it is lower by three orders of magnitude (0.003-0.007). This indicates that stibnite trapped essentially original fluids with no (or only minor) fractionation between $\mathrm{He}$ and $\mathrm{Ar}$, while the fluids trapped by the quartz had already lost the majority of the He fraction at the time of fluid entrapment.

\section{Discussion}

Microthermometric measurements of fluid inclusions hosted in stibnite yielded higher salinities and homogenization temperatures than fluid inclusions in quartz which implies there were at least two fluids of different origins involved in the mineralizing process at the Schlaining stibnite deposit. This is in line with the results of isotope and chemical analyses of fluid inclusions in quartz and stibnite presented here. The two fluids did not mix, which becomes obvious when plotting the isochores for fluid inclusions hosted in quartz and stibnite in a P-T diagram (Fig. 10). Assuming pressure conditions of less than $1 \mathrm{kbar}$ during fluid entrapment (Belocky et al. 1991), the isochores for aqueous fluid inclusions in quartz and stibnite do not intersect and exclude mixing of the two fluids.

Hydrothermal calcite associated with stibnite mineralization rarely contains aqueous carbonic inclusions in addition to aqueous two-phase inclusions (Belocky et al. 1991). $\mathrm{CO}_{2}$ was detected in the vapor phase of all quartzhosted aqueous two-phase inclusions analyzed by Raman spectroscopy. Traces of $\mathrm{CH}_{4}$ but no $\mathrm{H}_{2} \mathrm{~S}$ are contained besides $\mathrm{CO}_{2}$ in a few inclusions (Fig. 5). The salinities and homogenization temperatures of calcite-hosted fluid inclusions are similar to those of two-phase fluid inclusions in quartz (Belocky et al. 1991), suggesting that quartz 


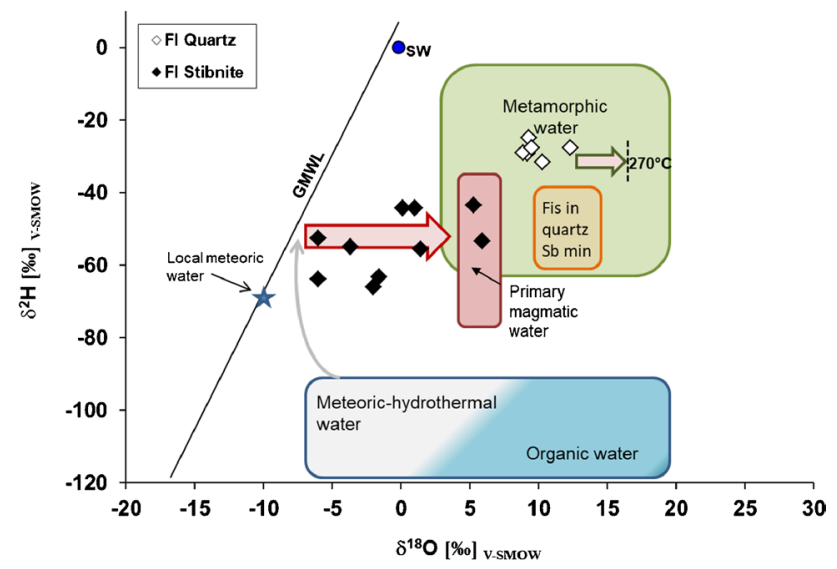

Fig. 8 Fluid inclusion water isotope data of quartz and stibnite. Whereas fluid inclusion isotope signatures of stibnite probably directly represent the mineralizing fluids, those in quartz may have experienced a post-depositional depletion in ${ }^{18} \mathrm{O}$ due to temperatureforced isotope re-equilibration (for details, see text). Considerable variations in $\delta^{2} \mathrm{H}_{\text {water }}$ exist among stibnite and quartz and indicate the existence of distinct fluid reservoirs. The water isotope composition of local meteoric mine water is marked by a star (Hager and Foelsche 2015). Field for fluid inclusion data of quartz from Alpine Austrian stibnite deposits (FIs in quartz Sb min) is shown for comparison (data compilation by Schroll and Prochaska 1997). The global meteoric water line (GMWL), which expresses the relation between $\delta^{2} \mathrm{H}_{\text {water }}$ and $\delta^{18} \mathrm{O}_{\text {water }}$ in natural terrestrial waters as a global average (Craig 1961), is shown for reference. Isotopic composition fields for waters of different origins are modified after Sheppard (1986). SW, seawater

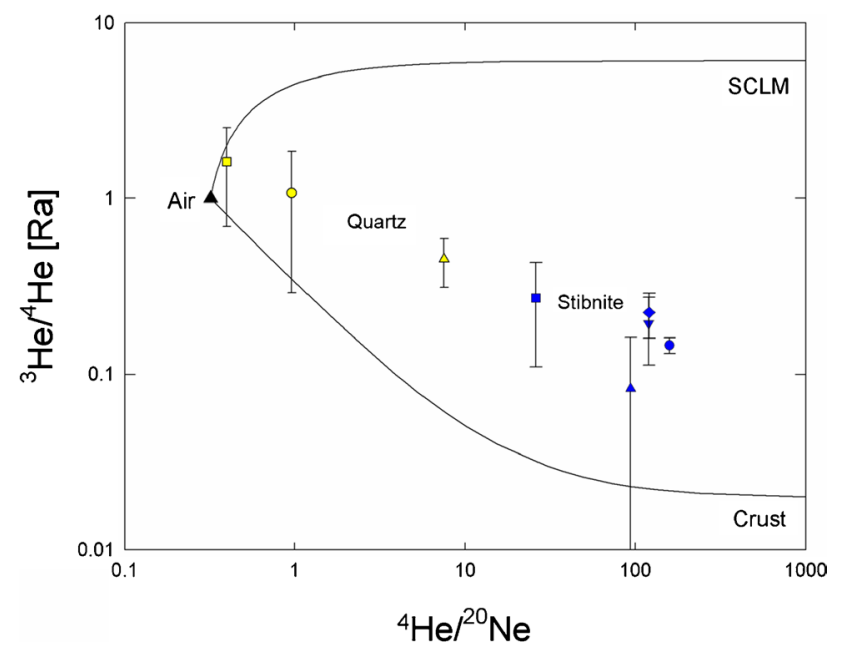

Fig. $9{ }^{3} \mathrm{He} /{ }^{4} \mathrm{He}$ vs. ${ }^{4} \mathrm{He} /{ }^{20} \mathrm{Ne}$ for fluid inclusions in quartz (yellow) and stibnite (blue). The same symbol shape for quartz and stibnite indicates that both minerals were collected for analysis from the same sample. Mixing lines between air and crust (Ballentine and Burnard 2002) and between air and subcontinental lithospheric mantle (SCLM; Gautheron and Moreira 2002) are also shown. Error limits are $2 \sigma$ and calcite precipitated from the same fluid, hereinafter named Fluid I. The ${ }^{87} \mathrm{Sr} /{ }^{86} \mathrm{Sr}$ isotope ratio of gangue calcite is between 0.712 and 0.713 (Grum et al. 1992) and is within the range of ${ }^{87} \mathrm{Sr} /{ }^{86} \mathrm{Sr}$ ratios typically reported for hydrothermal carbonates from carbonate-hosted mineralization of the Eastern Alps (Frimmel 1988; Frimmel and Niedermayr 1991). Greenschist rocks of the Pennine units are excluded as the $\mathrm{Sb}$ source due to their lower ${ }^{87} \mathrm{Sr} /{ }^{86} \mathrm{Sr}$ isotope ratios compared to vein calcite, with the prerequisite that calcite and stibnite precipitated from a single fluid (Grum et al. 1992). The same holds true for a direct relationship between the origin of the ore-forming fluid and andesitic volcanism (Grum et al. 1992). Instead, these authors favor models for the origin of the ore fluid that invokes (i) mobilization of Sb from hypothesized deepseated antimony mineralization by ascending metamorphic fluids or (ii) alteration of deep-seated crustal rock units by descending meteoric water and ore formation by fluid circulation and cooling into the Penninic calcareous schists. Grum et al. (1992) proposed a maximum age of 19-17 Ma for the stibnite mineralization and an epigenetic rather than a syn-sedimentary/early diagenetic origin (Nawaratne 1989). In contrast, Belocky et al. (1991) proposed a model that invokes localized high heat-flow triggered by Miocene andesitic magmatism and formation of epithermal stibnite mineralization at a shallow depth from low-salinity fluids at temperatures of at least $210^{\circ} \mathrm{C}$. A relationship between high heat flow, coalification of organic matter, and ore formation triggered by hidden magmatic intrusions in the Rechnitz Window is excluded by Dunkl et al. (1998). Instead, high heat flow is explained by tectonic denudation during the early Miocene (Dunkl et al. 1998).

There are several arguments to believe that the antimony mineralization of Schlaining is a typical epigenetic

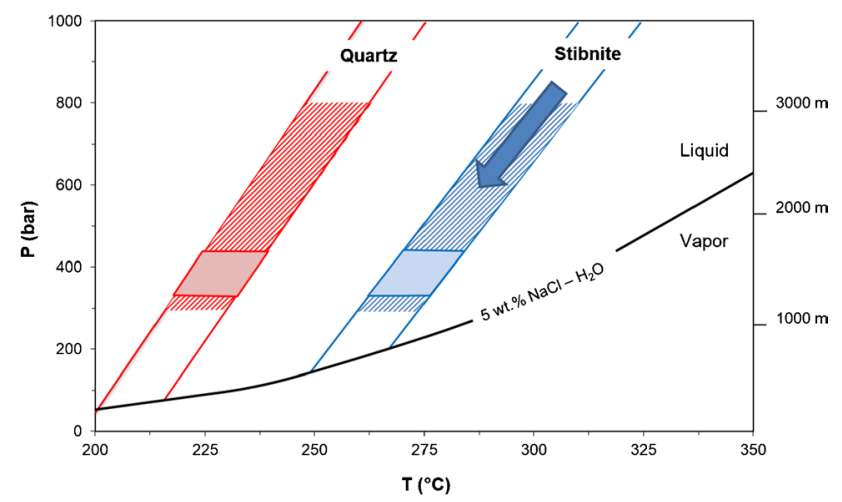

Fig. 10 Isochores for aqueous two-phase fluid inclusions in quartz and stibnite also showing the two-phase curve of a $5 \mathrm{wt} . \% \mathrm{NaCl}-\mathrm{H}_{2} \mathrm{O}$ fluid for a lithostatic pressure system (Cunningham 1978). Possible $\mathrm{P}-\mathrm{T}$ ranges of mineral deposition according to pressure estimates by Belocky et al. (1991) are shown in dashed lines. Colored fields are based on calculations of syn-rift burial by Dunkl et al. (1998) 
carbonate replacement deposit that was formed during the Miocene in response to fluid migration triggered by high heat flow induced by tectonic movements (Fig. 12). However, since a single fluid source for ore and gangue minerals in the Schlaining ore district can be excluded, previous geochemical studies that focussed on gangue minerals alone could have led to misleading conclusions about the origin of the ore fluid.

\section{Fluid origin and ore deposition}

The fluid inclusion salinity and homogenization temperatures from this study are consistent with those previously reported from quartz and calcite from the Schlaining $\mathrm{Sb}$ deposit (Belocky et al. 1991). The isotope data of the fluid that precipitated quartz (Fluid I) plot in the field of metamorphic water on the $\delta^{2} \mathrm{H}$ vs. $\delta^{18} \mathrm{O}$ diagram (Fig. 8). Considering oxygen isotope exchange reactions between fluid inclusions and quartz during cooling (Rye and O'Neil 1968), the measured $\delta^{18} \mathrm{O}_{\text {water }}$ values of 9 to $12 \%$ are too low and should be shifted to higher values (mean $17.3 \%$ at $270{ }^{\circ} \mathrm{C}$, see previous discussion regarding re-equilibration) but still plot within the metamorphic water field (Fig. 8). Analyses from quartz in other alpine $\mathrm{Sb}$ mineralization have reconstructed $\delta^{18} \mathrm{O}_{\text {water }}$ values between 10 and $14 \%$ and $\delta^{2} \mathrm{H}_{\text {water }}$ values between -40 and $-65 \%$ (Schroll and Prochaska 1997) and also plot in the field for metamorphic water in Fig. 8.

However, low-salinity metamorphic fluids are often characterized by the presence of $\mathrm{CO}_{2}$ that is released by volatilization reactions such as dehydration or decarbonation (e.g., Yardley and Cleverley 2015, and references therein). Consequently, aqueous-carbonic or $\mathrm{CO}_{2}$-bearing fluid inclusions are commonly found in quartz and/or carbonates from metamorphic environments including, for example, many $\mathrm{Au}$ deposits. Aqueous carbonic or carbonic inclusions were not observed in gangue quartz, but trace amounts of $\mathrm{CO}_{2}$ and $\mathrm{CH}_{4}$ were detected in quartz-hosted aqueous two-phase inclusions (Fig. 5). Similarly, rare $\mathrm{CO}_{2}$-bearing fluid inclusions were reported from gangue calcite that are assumed to originate from the same fluid as quartz (Belocky et al. 1991).

Whereas the $\delta^{18} \mathrm{O}_{\text {water }}$ record of quartz should be considered with caution, fluid inclusion water in stibnite is unlikely to have been affected by oxygen isotope exchange processes, since this mineral is devoid of oxygen. The water isotope compositions of stibnite-hosted fluid inclusions (Fluid II) strongly suggest a different, non-metamorphic origin of this fluid (Fig. 8). The low $\delta^{2} \mathrm{H}_{\text {water }}$ values ranging between -66.1 and $-43.3 \%$ exclude a seawater origin for Fluid II (e.g., Holser 1979). The $\delta^{18} \mathrm{O}_{\text {water }}$ values of fluid inclusions in stibnite essentially follow a horizontal evolution trend for meteoric water that has shifted towards higher $\delta^{18} \mathrm{O}_{\text {Water }}$ values due to water-rock interaction (e.g.,
Horita 2005). The contribution of secondary fluid inclusions in the WL sample does not show up clearly, since these secondary inclusions are likely to also be composed of meteoric water, which has a present-day isotope composition of around-10\% for $\delta^{18} \mathrm{O}$ and $-70 \%$ for $\delta^{2} \mathrm{H}$ in the area (Hager and Foelsche 2015). Interactions between deeply circulating heated meteoric water and Sb-bearing rocks such as black shales or greenschists are likely sources for the $\mathrm{Sb}$ and $\mathrm{H}_{2} \mathrm{~S}$ enrichment in Fluid II.

Whether it was interaction between heated meteoric water and sedimentary or other rocks that led to a significant uptake of $\mathrm{Sb}$ in Fluid II, the sulfur isotope ratios $\left(\delta^{34} \mathrm{~S}\right)$ from - 5.9 to $-8.4 \%$ (mean $-7.6 \%$ ) suggest a uniform source of sulfur (Pak et al. 1981). The negative $\delta^{34} \mathrm{~S}$ values point to a reduced sulfur source (e.g., sediments) rather than a magmatic (e.g., ophiolites) source if the fluid had not experienced significant changes in $\mathrm{pH}$ and/or $f_{\mathrm{O} 2}$ (Ohmoto and Lasaga 1982). At low $f_{\mathrm{O} 2}$ and $\mathrm{pH}$ values and a temperature of $250{ }^{\circ} \mathrm{C}$, the $\delta^{34} \mathrm{~S}$ values of sulfides would not differ significantly from an initial $\delta^{34} \mathrm{~S}_{\Sigma \mathrm{S}}$ of about $0 \%$ if the source was magmatic. High $f_{\mathrm{O} 2}$ values can be excluded as considerable amounts of barite would have precipitated (Ohmoto and Lasaga 1982) which is absent in the Schlaining district (Lehnert-Thiel 1967).

Stibnite solubility in hydrothermal fluids at about $300{ }^{\circ} \mathrm{C}$ (the temperature we have determined in this study) is extremely high regardless of the presence of $\mathrm{H}_{2} \mathrm{~S}, \mathrm{pH}$, or $f_{\mathrm{O} 2}$ but diminishes on cooling (Krupp 1988). Therefore, rapid cooling of $\mathrm{Sb}$-bearing fluids is believed to be the most important means of promoting stibnite precipitation (e.g., Munoz et al. 1992; Wagner and Cook 2000; Hagemann and Lüders 2003). Several studies of stibnite-hosted fluid inclusions using near-infrared light have revealed that worldwide stibnite precipitated from low to moderately saline fluids at temperatures mostly below $200{ }^{\circ} \mathrm{C}$ (e.g., Lüders 1996; Bailly et al. 2000; Germann et al. 2003; Buchholz et al. 2007; Sun et al. 2014; Shimizu 2018) or from $\mathrm{H}_{2} \mathrm{O}-\mathrm{CO}_{2}-\mathrm{NaCl}$-bearing fluids at temperatures up to $250^{\circ} \mathrm{C}$ (Hagemann and Lüders 2003; Krolop et al. 2018).

At temperatures above $300{ }^{\circ} \mathrm{C}$, high concentrations of $\mathrm{Sb}$ will be transported in the fluid as hydroxothioantimonite complexes $\mathrm{Sb}_{2} \mathrm{~S}_{2}(\mathrm{OH})_{2(\mathrm{aq})}$ (Krupp 1988) or hydroxide complexes $\mathrm{Sb}(\mathrm{OH})_{3(\mathrm{aq})}$ (Zotov et al. 2003) rather than bisulfide complexes, e.g., $\mathrm{Sb}_{2} \mathrm{~S}_{4}{ }^{2-}, \mathrm{HSb}_{2} \mathrm{~S}_{4}{ }^{-}, \mathrm{H}_{2} \mathrm{Sb}_{2} \mathrm{~S}_{4(\text { aq) }}$. Both hydroxybisulfide and hydroxide species are stable over a wide range of $\mathrm{pH}$ conditions (acidic and acidic to near-neutral, respectively) and form at low $\mathrm{H}_{2} \mathrm{~S}$ activities in the fluid (Krupp 1988; Williams-Jones and Norman 1997; Hagemann and Lüders 2003). A low $\mathrm{H}_{2} \mathrm{~S}$ activity is assumed based on the lack of other accompanying sulfide precipitation during the main Sb mineralization stage. The low salinities (5.7-7.1 wt.\% $\mathrm{NaCl}$ equiv.) in primary fluid inclusions confirm that chloride complexes did not contribute to the transport of $\mathrm{Sb}$ in the hydrothermal fluid. Changes in the physico-chemical conditions are required to destabilize the metal transporting complexes leading to stibnite precipitation. Adiabatic cooling 


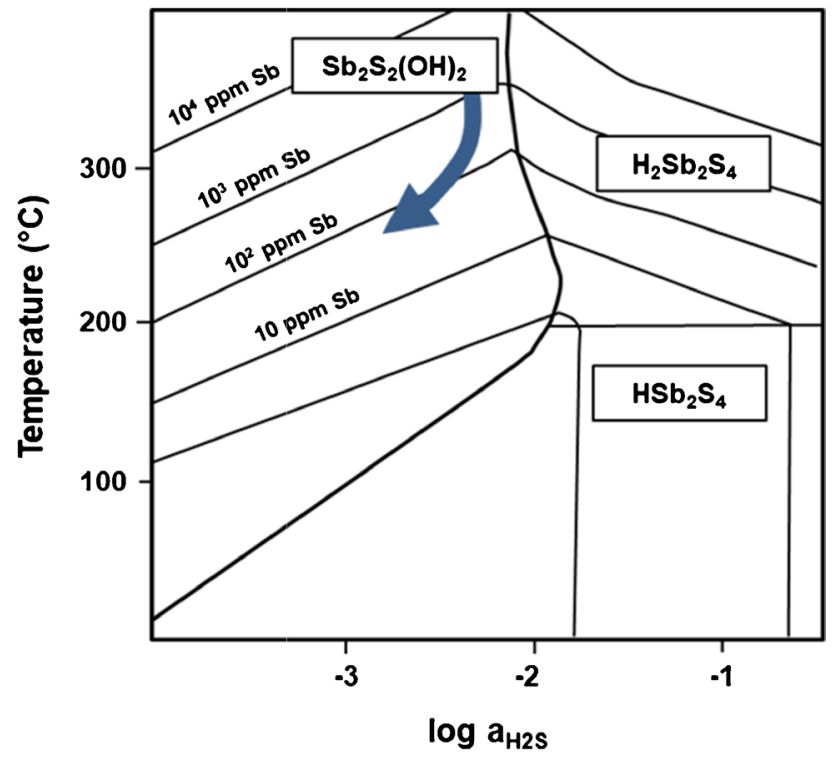

Fig. 11 Solubility contours (in ppm Sb) for stibnite and specification of aqueous $\mathrm{Sb}$ as a function of $\mathrm{T}$ and $\log \mathrm{aH}_{2} \mathrm{~S}$ at constant $\mathrm{pH}$ of 5.5 (Hagemann and Lüders 2003). The arrow illustrates a hypothesized path of an ore fluid. Cooling of the fluid reduces Sb solubility and causes stibnite precipitation. Stibnite deposition also reduces $\mathrm{H}_{2} \mathrm{~S}$ activity

of hydrothermal Sb-bearing fluids below about $300{ }^{\circ} \mathrm{C}$ reduces the $\mathrm{Sb}$ solubility considerably and induces stibnite precipitation (Fig. 11). The stibnite-forming reaction involves the consumption of $\mathrm{H}_{2} \mathrm{~S}$ from the fluid (Krupp 1988):

$$
1 / 2 \mathrm{Sb}_{2} \mathrm{~S}_{2}(\mathrm{OH})_{2}+1 / 2 \mathrm{H}_{2} \mathrm{~S}=1 / 2 \mathrm{Sb}_{2} \mathrm{~S}_{3}+\mathrm{H}_{2} \mathrm{O}
$$

The microthermometric data from stibnite-hosted primary and pseudo-secondary fluid inclusions define a cooling trend, at relatively stable salinities (Fig. 6) and together with the mono-mineralic stibnite ore confirm the likelihood that cooling below $300{ }^{\circ} \mathrm{C}$ induced ore formation.

Under such temperature conditions, a maximum pressure of $\sim 800$ bar during stibnite formation can be derived from Fig. 10. Assuming pressure conditions close to lithostatic and a density of $2.6 \mathrm{~g} / \mathrm{cm}^{3}$, the stibnite deposit at Schlaining therefore formed at a maximum depth of about $3 \mathrm{~km}$. Belocky et al. (1991) suggested that the stibnite mineralization at Schlaining formed at shallow depth and estimated pressure conditions between 300 and 800 bar (dashed fields in Fig. 10) corresponding to depths between 1200 and 3000 m (Fig. 10). Dunkl et al (1998) calculated that the syn-rift burial depth of the hanging wall margin of the Rechnitz Window was 1100 to $1600 \mathrm{~m}$. At such depths, stibnite deposition would have occurred at pressures between about 300 and 400 bar (lithostatic pressure conditions) and temperatures between about 260 and $280{ }^{\circ} \mathrm{C}$ (Fig. 10). Quartz would have been deposited at temperatures between about 220 and $240{ }^{\circ} \mathrm{C}$ (Fig. 10). There is compelling evidence that fluids from at least two different sources at temperatures greater than $250{ }^{\circ} \mathrm{C}$ were involved in ore and gangue mineral formation in the area of the Rechnitz Window. Fluid release and migration were probably related to high heat flow during the Early Miocene (Fig. 12). This was in response to the rapid uplift of the Mesozoic Penninic units with contemporaneous subduction along the Carpathian arc and opening of the Pannonian Basin (Ratschbacher et al. 1990; Dunkl and Demény 1997; Dunkl et al. 1998). However, there is a suggestion that the migration of fluids and ore deposition at Schlaining was triggered by Miocene andesitic magmatism (Belocky et al. 1991) or by high heat flow related to tectonic denudation during the early Miocene (Dunkl et al. 1998).

Although the sources of major ore components for stibnite mineralization are not definitely known, the fluid origin can be constrained based on the results of this study. The He isotope ratios indicate the presence of a mantle He component in the fluid inclusions which was probably derived from Miocene andesites. However, Fu et al. (2020) have shown that primary magmatic fluids are not enriched in $\mathrm{Sb}$ and thus do not contribute directly to the metal budget of economic stibnite deposits. $\delta^{2} \mathrm{H}$ and $\delta^{18} \mathrm{O}$ isotope ratios of stibnite-hosted fluid inclusions indicate that stibnite was very likely deposited from a meteoric fluid. Assuming that the ore-forming fluid was saturated with respect to $\mathrm{H}_{2} \mathrm{~S}$, the negative $\delta^{34} \mathrm{~S}$ values of stibnite point to a supply of sulfur and $\mathrm{Sb}$ leached from black shales or metasediments such as greenschists rather than from Miocene andesites or surrounding ophiolites including altered MORB (Jochum and Verma 1996). It is also unclear whether the fluids originated from reservoirs located in the Eastern Alps or if the ore Fluid II was expelled from the Pannonian Basin and migrated along deep-reaching shear zones (Fig. 13). However, a selection/exclusion of possible fluid sources solely based on $\mathrm{Sr}$ isotope ratios in gangue calcite alone (Grum et al. 1992) is problematic as this study has shown that stibnite precipitated from a different fluid to calcite. Conclusions based on fluid inclusions in quartz which are clearly different to those in stibnite will also lead to errors. In the Schlaining mining district, quartz was precipitated from $\mathrm{CO}_{2}$-bearing metamorphic Fluid I, which most likely originated from distal Paleozoic greywackes or gneisses in the basement. Although fluids that precipitated quartz and stibnite had a different origin, 


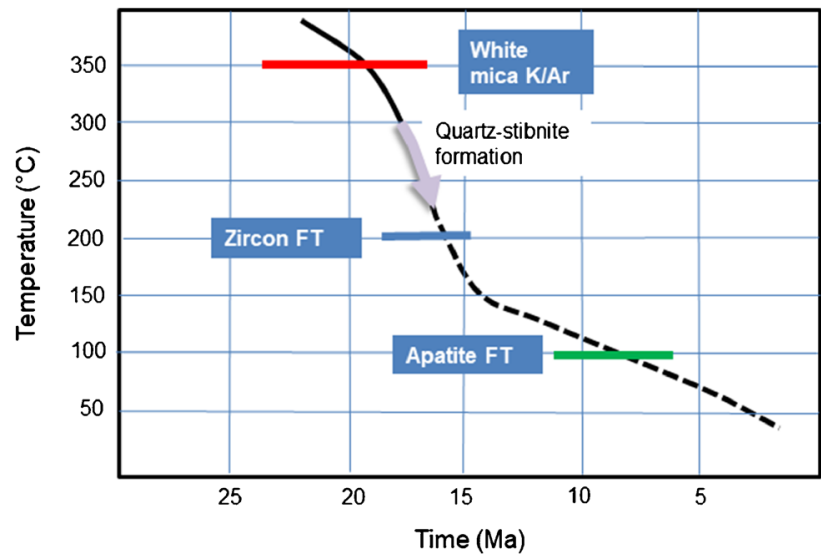

Fig. 12 Simplified cooling curve for the exhumation of the Rechnitz Window (after Dunkl et al. 1998) and the possible temperature time frame for deposition of the Schlaining $\mathrm{Sb}$ mineralization. Colored bars show the ranges of K/Ar ages for white mica and fission track ages for zircons and apatite. After a period of rapid folding which lasts from ca. 22 to $17 \mathrm{Ma}$, exhumation slowed down from $2 \mathrm{~mm} / \mathrm{a}$ (solid line in the curve) to about $0.29 \mathrm{~mm} / \mathrm{a}$ (dashed line). Quartzstibnite mineralization is likely related to the period of rapid uplift

they did so at the same time in the deposit without mixing with each other.

\section{Conclusions}

Comprehensive analyses of fluid inclusions hosted in quartz and stibnite document the involvement of at least two fluids from different sources that were responsible for the formation of (i) gangue minerals and (ii) stibnite at the Schlaining $\mathrm{Sb}$ deposit.

Quartz-(calcite)-forming Fluid I was of metamorphic origin and is characterized by a salinity similar to seawater and low $\mathrm{CO}_{2}$ concentration. The abundance of non-atmospheric $\mathrm{He}$ in fluid inclusions is considerably lower in quartz than in stibnite.

Stibnite-forming Fluid II originally was of meteoric origin that seeped down along permeable structures into a hot reaction zone where it became enriched in the mantle and crustal $\mathrm{He}, \mathrm{Sb}$, and $\mathrm{H}_{2} \mathrm{~S}$ by interaction with sediments, probably black shales and/or metasedimentary rocks (e.g., phylites, greenschists).

Both fluids did not mix at the depositional site. Stibnite deposition occurred by cooling of Fluid II from temperatures of about $300-260{ }^{\circ} \mathrm{C}$, at shallow depth, below $2000 \mathrm{~m}$, i.e., under epithermal conditions. Fluid migration and ore deposition are likely related to high heat flow in response to Neogene extension and/or shallow Early Miocene andesitic magmatism.

Our study emphasizes that data obtained from geochemical analyses of gangue minerals cannot routinely be used to infer the origin and depositional conditions of the associated

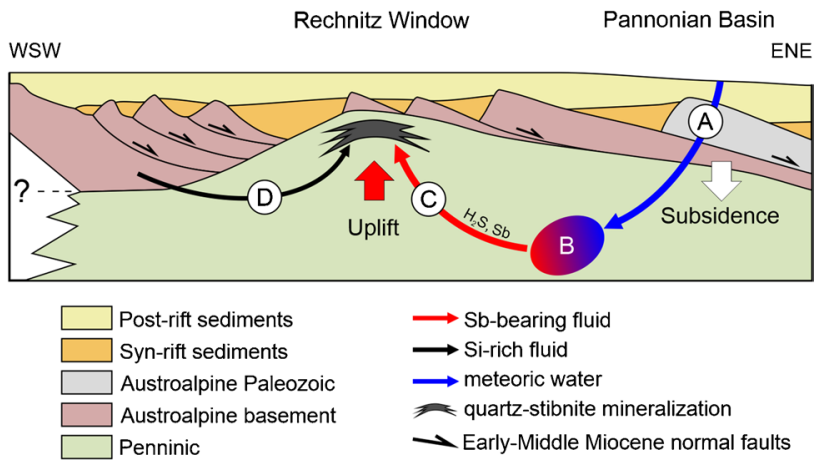

Fig. 13 Cross section of the Rechnitz Window (after Dunkl et al. 1998) showing the situation in the Miocene at the likely time of ore formation. Meteoric water that discharged during rifting (A) reacted with shales or greenschists at greater depth (B). The hot fluid enriched in $\mathrm{H}_{2} \mathrm{~S}$ and $\mathrm{Sb}$ ascended during the uplift of the Rechnitz Window and caused stibnite deposition in the Schlaining ore district (C). The migration of a quartz-forming fluid (D) that originated from a different source to the site of mineralization ocurred contemperaneously

ore minerals. Thus, all conclusions concerning the origin and formation of the Schlaining stibnite deposit that are based on results, e.g., of fluid inclusion studies in gangue minerals or $\mathrm{Sr}$ isotope ratios in gangue calcite only have to be considered with caution.

Acknowledgements We are particularly indebted to R.T. Schmitt (Museum für Naturkunde Berlin), W. Ließmann (TU Clausthal), and F. Melcher (Montanuniversität Leoben) for providing the sample material from the Schlaining stibnite deposit. We are also grateful for the technical assistance of C. Preinfalk (München) and E. Schnabel (GFZ Potsdam). We would like to thank Mineralium Deposita chief editor B. Lehmann and W. Pohl for the critical review of the manuscript and useful comments.

Funding Open Access funding enabled and organized by Projekt DEAL.

Open Access This article is licensed under a Creative Commons Attribution 4.0 International License, which permits use, sharing, adaptation, distribution and reproduction in any medium or format, as long as you give appropriate credit to the original author(s) and the source, provide a link to the Creative Commons licence, and indicate if changes were made. The images or other third party material in this article are included in the article's Creative Commons licence, unless indicated otherwise in a credit line to the material. If material is not included in the article's Creative Commons licence and your intended use is not permitted by statutory regulation or exceeds the permitted use, you will need to obtain permission directly from the copyright holder. To view a copy of this licence, visit http://creativecommons.org/licenses/by/4.0/.

\section{References}

Arienzo MM, Swart PK, Vonhof HB (2013) Measurement of $\delta^{18} \mathrm{O}$ and $\delta^{2} \mathrm{H}$ values of fluid inclusion water in speleothems using cavity ring-down spectroscopy compared with isotope ratio mass 
spectrometry. Rapid Commun Mass Spectrom 27:2616-2624. https://doi.org/10.1002/rcm.6723

Bailly L, Bouchot V, Bény C, Milési J-P (2000) Fluid inclusion study of stibnite using infrared microscopy: an example from the Brouzils antimony deposit (Vendée, Armorican massif, France). Econ Geol 95:221-226. https://doi.org/10.2113/gsecongeo.95.1.221

Ballentine CJ, Burnard PG (2002) Production, release and transport of noble gases in the continental crust. Rev Mineral Geochem 47:481-538. https://doi.org/10.2138/rmg.2002.47.12

Banks DA, Boyce AJ, Samson IM (2002) Constraints on the origins of fluids forming Irish $\mathrm{Zn}-\mathrm{Pb}-\mathrm{Ba}$ deposits: evidence from the composition of fluid inclusions. Econ Geol 97:471-480. https://doi. org/10.2113/gsecongeo.97.3.471

Banks DA, Giuliani G, Yardley BWD, Cheilletz A (2000) Emerald mineralisation in Colombia: fluid chemistry and the role of brine mixing. Miner Deposita 35:699-713. https://doi.org/10. 1007/s001260050273

Bauer F (1966) Gefügekundliche Beobachtungen in der Antimonitlagerstätte Schlaining im Burgenland. Verh Geol Bundesanstalt Wien 70-76

Belocky R, Sachsenhofer R, Pohl W (1991) Neue Argumente für eine epithermale Genese der Antimonerzlagerstätte Schlaining (Burgenland/Österreich): Flüssigkeitseinschlußuntersuchungen und das Inkohlungsbild der benachbarten Tertiärbecken. BergHüttenmänn Monatsh 136:209-213

Bodnar RJ (1993) Revised equation and table for determining the freezing point depression of $\mathrm{H}_{2} \mathrm{O}-\mathrm{NaCl}$ solutions. Geochim Cosmochim Ac 57:683-684. https://doi.org/10.1016/0016-7037(93) 90378-A

Bortnikov NS, Gamynin GN, Vikent'eva OV, et al (2010) The Sarylakh and Sentachan gold-antimony deposits, Sakha-Yakutia: a case of combined mesothermal gold-quartz and epithermal stibnite ores. Geol Ore Deposits 52:339-372. https://doi.org/ 10.1134/S1075701510050028

Buchholz P, Oberthür T, Lüders V, Wilkinson J (2007) Multistage $\mathrm{Au}-\mathrm{As}$-Sb mineralization and crustal-scale fluid evolution in the Kwekwe District, Midlands Greenstone Belt, Zimbabwe: a combined geochemical, mineralogical, stable isotope, and fluid inclusion study. Econ Geol 102:347-378. https://doi.org/ 10.2113/gsecongeo.102.3.347

Chovan M, Schroll E, Andráš P et al (2002) Stibnite mineralization of Western Carpathians and Eastern Alps: geological, mineralogical, and geochemical features. Geologica Carpathica Special Issue, Proceedings of XVII Congress of Carpathian-Balkan Geological Association, Bratislava 53:1-7

Clayton RN, O'Neil JR, Mayeda TK (1972) Oxygen isotope exchange between quartz and water. J Geophys Res 77:3057-3067. https:// doi.org/10.1029/JB077i017p03057

Craig H (1961) Isotopic variations in meteoric waters. Science 133:1702-1703. https://doi.org/10.1126/science.133.3465.1702

Cunningham CG (1978) Pressure gradients and boiling as mechanisms for localizing ore in porphyry systems. J Res US Geol Surv. 6:745754

Davisson ML, Criss RE (1996) Na-Ca-Cl relations in basinal fluids. Geochim Cosmochim Ac 60:2743-2752. https://doi.org/10. 1016/0016-7037(96)00143-3

de Graaf S, Lüders V, Banks DA et al (2020a) Fluid evolution and ore deposition in the Harz Mountains revisited: isotope and crushleach analyses of fluid inclusions. Miner Deposita 55:47-62. https://doi.org/10.1007/s00126-019-00880-w

de Graaf S, Vonhof HB, Weissbach T et al (2020b) A comparison of isotope ratio mass spectrometry and cavity ring-down spectroscopy techniques for isotope analysis of fluid inclusion water. Rapid Commun Mass Spectrom 34:e8837. https://doi.org/10. $1002 / \mathrm{rcm} .8837$
Dill H (1993) Die Antimon-Vorkommen der mitteleuropäischen Alpiden und Varisziden. Zeitschr Deutsch Geol Ges 144:434-450

Dill HG (1998) Evolution of Sb mineralisation in modern fold belts: a comparison of the $\mathrm{Sb}$ mineralisation in the Central Andes (Bolivia) and the Western Carpathians (Slovakia). Mineral Deposita 33:359-378. https://doi.org/10.1007/s001260050155

Dunkl I (1992) Final episodes of the cooling history of the eastern termination of the Alps. In: Neubauer, F. (ed) ALCAPA Field guide. Graz, pp 137-139

Dunkl I, Demény A (1997) Exhumation of the Rechnitz Window at the border of the Eastern Alps and Pannonian Basin during Neogene extension. Tectonophys 272:197-211. https://doi.org/ 10.1016/S0040-1951(96)00258-2

Dunkl I, Grasemann B, Frisch W (1998) Thermal effects of exhumation of a metamorphic core complex on hanging wall synrift sediments: an example from the Rechnitz Window, Eastern Alps. Tectonophys 297:31-50. https://doi.org/10.1016/S00401951(98)00162-0

Dunkl I, Koller F (2001) Penninic of the Rechnitz window group (REW) In: Dunkl I, Balintoni I, Frisch W, Janák M, Koroknai B, Milovanovic D, Pamic D, Székely B, Vrabec M (eds) Metamorphic map and database of Carpatho-Balkan-Dinaride area. http://www.met-map.uni-goettingen.de

Fan D, Zhang T, Ye J (2004) The Xikuangshan Sb deposit hosted by the Upper Devonian black shale series, Hunan, China. Ore Geol Rev 24:121-133. https://doi.org/10.1016/j.oregeorev.2003. 08.005

Favaro S, Schuster R, Handy MR et al (2015) Transition from orogen-perpendicular to orogen-parallel exhumation and cooling during crustal indentation - key constraints from ${ }^{147} \mathrm{Sm} /{ }^{144} \mathrm{Nd}$ and ${ }^{87} \mathrm{Rb} /{ }^{87} \mathrm{Sr}$ geochronology (Tauern Window, Alps). Tectonophys 665:1-16. https://doi.org/10.1016/j.tecto.2015.08. 037

Feitzinger G, Paar WH, Tarkian M et al (1995) Vein type Ag-(Au)-Pb, $\mathrm{Zn}, \mathrm{Cu}-(\mathrm{W}, \mathrm{Sn})$ mineralization in the Southern Kreuzeck Mountains, Carinthia province, Austria. Mineral Petrol 53:307-332. https://doi.org/10.1007/BF01160154

Fontes JCh, Matray JM (1993) Geochemistry and origin of formation brines from the Paris Basin, France: 2. Saline solutions associated with oil fields. Chem Geol 109:177-200. https://doi.org/10.1016/ 0009-2541(93)90069-U

Frimmel H (1988) Strontium isotopic evidence for the origin of siderite, ankerite and magnesite mineralizations in the Eastern Alps. Mineral Deposita 23:268-275. https://doi.org/10.1007/BF002 06407

Frimmel HEE, Niedermayr G (1991) Strontium isotopes in magnesites from Permian and Triassic strata, Eastern Alps. J Appl Geochem 6:89-96. https://doi.org/10.1016/0883-2927(91) 90065-W

Fu S, Zajacz Z, Tsay A, Hu R (2020) Can magma degassing at depth donate the metal budget of large hydrothermal Sb deposits? Geochim Cosmochim Ac 290:1-15. https://doi.org/10.1016/j.gca. 2020.08.029

Gautheron C, Moreira M (2002) Helium signature of the subcontinental lithospheric mantle. Earth Planet Sci Lett 199:39-47. https://doi. org/10.1016/S0012-821X(02)00563-0

Grum W, Frimmel HE, Koller F (1992) Sr-Isotopendaten zur Genese der Antimonit-Lagerstätte Schaining. Mitt Ges Geol Berbaustud Österr 38:73-92

Gumiel P, Arribas A (1987) Antimony deposits in the Iberian Peninsula. Econ Geol 82:1453-1463. https://doi.org/10.2113/gseco ngeo.82.6.1453

Hagemann SG, Lüders V (2003) P-T-X conditions of hydrothermal fluids and precipitation mechanism of stibnite-gold mineralization at the Wiluna lode-gold deposits, Western Australia: conventional 
and infrared microthermometric constraints. Miner Deposita 38:936-952. https://doi.org/10.1007/s00126-003-0351-6

Hager B, Foelsche U (2015) Stable isotope composition of precipitation in Austria. Austrian J Earth Sci 108. https://doi.org/10.17738/ ajes.2015.0012

Hiessleitner G (1947) Die geologischen Grundlagen des AntimonBergbaues in Österreich. Jb Geol B-A 92:1-92

Hoinkes G, Koller F, Rantitsch G (1999) Alpine metamorphism of the Eastern Alps. Schweiz Mineral Petrogr Mitt 79:155-181. https:// doi.org/10.5169/SEALS-60203

Höll R (1978) Time-and stratabound early Paleozoic scheelite, stibnite and cinnabar deposits in the Eastern Alps. Verh Geol B A Wien 3:369-387

Holser WT (1979) Trace elements and isotopes in evaporites. In: Burns RG (ed) Marine Minerals. Reviews in Mineralogy, Mineral. Soc. Am., De Gruyter, pp 295-346

Horita J (2005) Saline waters. In: Aggarwal PK, Gat JR, Froehlich KFO (eds) Isotopes in the water cycle: past, present and future of a developing science. Springer, Netherlands, Dordrecht, pp 271-287

Jochum KP, Verma SP (1996) Extreme enrichment of Sb, Tl and other trace elements in altered MORB. Chem Geol 130:289 299. https://doi.org/10.1016/0009-2541(96)00014-9

Koller F (1985) Petrologie und Geochemie der Ophiolite des Penninikums am Alpenostrand. Jb Geol B-A 128:83-150

Krolop P, Burisch M, Richter L et al (2019) Antimoniferous veintype mineralization of the Berga Antiform, Eastern-Thuringia, Germany: a fluid inclusion study. Chem Geol 508:47-61. https://doi.org/10.1016/j.chemgeo.2018.02.034

Krupp RE (1988) Solubility of stibnite in hydrogen sulfide solutions, speciation, and equilibrium constants, from 25 to $350^{\circ} \mathrm{C}$. Geochim Cosmochim Ac 52:3005-3015. https://doi.org/10.1016/ 0016-7037(88)90164-0

Lehnert-Thiel K (1967) Ein Beitrag zur Paragenese und Generationenabfolge in der Antimonlagerstätte von Schlaining/Burgenland. Archiv Für Lagerstättenforschung in Den Ostalpen 5:16-31

Liu JM, Ye J (2005) A sedex-type stibnite-only deposit in the giant metallogenic Sb belt, South China. In: Mao J, Bierlein FP (eds) Mineral deposit research: meeting the global challenge. Springer, Berlin, Heidelberg, pp 1411-1414

Lüders V (2017) Contribution of infrared microscopy to studies of fluid inclusions hosted in some opaque ore minerals: possibilities, limitations, and perspectives. Miner Deposita 52:663-673. https:// doi.org/10.1007/s00126-016-0694-4

Lüders V (1996) Contribution of infrared microscopy to fluid inclusion studies in some opaque minerals (wolframite, stibnite, bournonite); metallogenic implications. Econ Geol 91:1462-1468. https:// doi.org/10.2113/gsecongeo.91.8.1462

Maucher A, Höll R (1968) Die Bedeutung geochemisch-stratigraphischer Bezugshorizonte für die Altersstellung der Antimonitlagerstätte von Schlaining im Burgenland, Österreich. Miner Deposita 3:272-285. https://doi.org/10.1007/BF00207440

Möller P, Lüders V, De Lucia M (2017) Formation of Rotliegend Ca-Cl brines in the North German Basin compared to analogues in the geological record. Chem Geol 459:32-42. https://doi.org/10. 1016/j.chemgeo.2017.04.001

Moritz R (2006) Fluid salinities obtained by infrared microthermometry of opaque minerals: Implications for ore deposit modeling - a note of caution. J Geochem Expl 89:284-287. https://doi.org/10. 1016/j.gexplo.2005.11.068

Nawaratne S (1989) Geochemische, petrologische und isotopen-geochemische Untersuchungen in Bezug auf die Genese der Antimonlagerstätten in den Ostalpen mit besonderer Berücksichtigung der Lagerstätte von Schlaining im Burgenland, Österreich. PhD Thesis, University of Vienna

Niedermann S, Bach W, Erzinger J (1997) Noble gas evidence for a lower mantle component in MORBs from the southern East Pacific Rise: decoupling of helium and neon isotope systematics. Geochim Cosmochim Ac 61:2697-2715. https://doi.org/10.1016/ S0016-7037(97)00102-6

Ohmoto H, Lasaga AC (1982) Kinetics of reactions between aqueous sulfates and sulfides in hydrothermal systems. Geochim Cosmochim Ac 46:1727-1745. https://doi.org/10.1016/0016-7037(82) 90113-2

Pak E, Schroll E, Schulz O (1981) Zur Schwefelisotopenzusammensetzung des Antimonits von Schlaining Burgenland. Anzeiger Der Akademie Der Wissenschaften in Wien 118:21-23

Peng H-W, Fan H-R, Santosh M et al (2020) Infrared microthermometry of fluid inclusions in transparent to opaque minerals: challenges and new insights. Miner Deposita 55:1425-1440. https:// doi.org/10.1007/s00126-019-00950-z

Peng J, Hu R, Zau L (2002) Isotope tracing of ore-forming materials for the Xikuangshan antimony deposit, central Hunan. Acta Minera Sin 22:155-159

Petrascheck W (1978) Zur Altersbestimmung einiger ostalpiner Erzlagerstätten. Mitt Österr Geol Ges 68:79-87

Pohl W (2020) Economic geology: Principles and practice: Metals, minerals, coal and hydrocarbons - Introduction to formation and sustainable exploitation of mineral deposits, 2nd revised edn. Schweizerbart Science Publishers, Stuttgart, Germany, $755 \mathrm{p}$

Pohl W, Belocky R (1994) Alpidic metamorphic fluids and metallogenesis in the Eastern Alps. Mitt Österr Geol Ges 86:141-152

Pollak A (1953) Zur Geologie und wirtschaftlichen Bedeutung der Antimonerzlagerstätte Schlaining in Österreich. Freiberger Forschungshefte C 5:18-21

Pollak A (1955) Neuere Untersuchungen auf der Antimonitlagerstätte Schlaining. Berg-Hüttenmänn Monatsh 100:137-145

Ramsey MH, Wiedenbeck M (2018) Quantifying isotopic heterogeneity of candidate reference materials at the picogram sampling scale. Geostand Geoanal Res 42:5-24. https://doi.org/10.1111/ ggr.12198

Ratschbacher L, Behrmann JH, Pahr A (1990) Penninic windows at the eastern end of the Alps and their relation to the intra-Carpathian basins. Tectonophysics 172:91-105. https://doi.org/10.1016/00401951(90)90061-C

Rye RO, O'Neil JR (1968) The $\mathrm{O}^{18}$ content of water in primary fluid inclusions from Providencia, north-central Mexico. Econ Geol 63:232-238. https://doi.org/10.2113/gsecongeo.63.3.232

Schmid W (1956) Exkursion ins mittlere Burgenland: Die Schieferinseln am Ostrand der Zentralalpen. Mitt Geol Ges Wien 360-365

Schönlaub HP (1973) Schwamm-Spiculae aus dem Rechnitzer Schiefergebirge und ihr stratigraphischer Wert. Jb Geol Bundesanst 116:35-49

Schroll E, Prochaska W (1997) Wasserstoff- Und Sauerstoffisotope Arch Lagerstättenforsch 19:449-451

Sheppard SMF (1986) Characterization and isotopic variations in natural waters. Rev Mineral Geochem 16:165-183

Shimizu T (2018) Fluid inclusion studies of comb quartz and stibnite at the Hishikari Au-Ag epithermal deposit, Japan. Resour Geol 68:326-335. https://doi.org/10.1111/rge.12168

Steele-MacInnis M, Lecumberri-Sanchez P, Bodnar RJ (2012) HokieFlincs_H $\mathrm{H}_{2} \mathrm{O}-\mathrm{NaCl}$ : a Microsoft Excel spreadsheet for interpreting microthermometric data from fluid inclusions based on the PVTX properties of $\mathrm{H}_{2} \mathrm{O}-\mathrm{NaCl}$. Comput Geosci 49:334-337. https://doi.org/10.1016/j.cageo.2012.01.022

Taylor HP Jr (1997) Oxygen and hydrogen isotope relationships in hydrothermal mineral deposits. In: Barnes HL (ed) Geochemistry 
of hydrothermal ore deposits, 3rd edn. John Wiley \& Sons, New York, pp 229-302

Wagner T, Boyce AJ (2003) Sulphur isotope geochemistry of black shale-hosted antimony mineralization, Arnsberg, northern Rhenish Massif, Germany: implications for late-stage fluid flow during the Variscan orogeny. J Geol Soc 160:299-308. https://doi.org/10. 1144/0016-764902-010

Weber L (1989) Zur Geologie der Antimonvererzungen des Osttiroler Anteils der Kreuzeckgruppe. Arch f Lagerst.forsch Geol B-A 10:65-74

Williams-Jones AE, Norman C (1997) Controls of mineral parageneses in the system Fe-Sb-S-O. Econ Geol 92:308-324. https://doi.org/ 10.2113/gsecongeo.92.3.308

Yang D, Shimizu M, Shimazaki H et al (2006) Sulfur isotope geochemistry of the supergiant Xikuangshan Sb deposit, Central Hunan,
China: constraints on sources of ore constituents. Resour Geol 56:385-396. https://doi.org/10.1111/j.1751-3928.2006.tb00291.x

Yardley BWD, Cleverley JS (2015) The role of metamorphic fluids in the formation of ore deposits. Geological Society, London, Special Publications 393:117-134. https://doi.org/10.1144/SP393.5

Zotov AV, Shikina ND, Akinfiev N (2003) Thermodynamic properties of the $\mathrm{Sb}(\mathrm{III})$ hydroxide complex $\mathrm{Sb}(\mathrm{OH})_{3}(\mathrm{aq})$ at hydrothermal conditions. Geochim Cosmochim Ac 67:1821-1836. https://doi. org/10.1016/S0016-7037(02)01281-4

Publisher's note Springer Nature remains neutral with regard to jurisdictional claims in published maps and institutional affiliations. 